ISSN 1999-4915

www.mdpi.com/journal/viruses

Review

\title{
Antiviral Treatment of Chronic Hepatitis B Virus (HBV) Infections $^{\dagger}$
}

\section{Erik De Clercq, Geoffrey Férir, Suzanne Kaptein and Johan Neyts *}

Rega Institute for Medical Research, K.U. Leuven, Minderbroedersstraat 10, B-3000 Leuven, Belgium; E-Mails: geoffrey.ferir@rega.kuleuven.be (G.F.); suzanne.kaptein@rega.kuleuven.be (S.K.)

$\dagger$ This paper is to be considered as a revised and updated version of the paper published by Férir et al.:

Ferir, G.; Kaptein, S.; Neyts, J., De Clercq, E. Antiviral treatment of chronic hepatitis B virus infections: the past, the present and the future. Rev. Med. Virol. 2008, 18, 19-34.

* Author to whom correspondence should be addressed; E-Mail: johan.neyts@rega.kuleuven.be;

Tel: +32-16-337367; Fax: + 32-16-337340.

Received: 9 March 2010; in revised form: 18 May 2010 / Accepted: 25 May 2010 /

Published: 31 May 2010

\begin{abstract}
While 25 compounds have been formally licensed for the treatment of HIV infection (AIDS), only seven licensed products are currently available for the treatment of chronic hepatitis B virus (HBV) infection: interferon- $\alpha$, pegylated interferon- $\alpha$, lamivudine, adefovir (dipivoxil), entecavir, telbivudine and tenofovir (disoproxil fumarate). In contrast to the treatment of HIV infections where the individual drugs are routinely used in combination, for the treatment of chronic HBV infection the individual drugs are generally used in monotherapy. In principle, combination drug therapy should allow reducing the likelihood of drug-resistant development.
\end{abstract}

Keywords: antiviral therapy; HBV therapy; nucleoside analogs; viral hepatitis

\section{Abbreviations}

3TC

- $\quad$ Lamivudine [(-) $\beta$-L-2',3'-dideoxy-3'-thiacytidine]

3TC-TP

3TC-triphosphate

cccDNA

covalently closed circular DNA 


$\begin{array}{lll}\text { CHB } & - & \text { Chronic Hepatitis B } \\ \text { dCTP } & - & \text { Deoxycytidine Triphosphate } \\ \text { DDDP } & - & \text { Viral DNA - Dependent DNA Polymerase } \\ \text { DHBV } & - & \text { Duck Hepatitis B Virus } \\ \text { DR } & - & \text { Direct Repeat } \\ \text { dsl } & - & \text { double-stranded linear } \\ \text { EC } 50 & - & 50 \% \text { Effective (inhibitory) Concentration } \\ \text { FDA } & - & \text { Food and Drug Administration } \\ (-) F T C & - & \text { Emtricitabine } \\ \text { HBcAg } & - & \text { Hepatitis B core Antigen } \\ \text { HBeAg } & - & \text { Hepatitis B e Antigen } \\ \text { HBsAg } & - & \text { Hepatitis B surface Antigen } \\ \text { HBV } & - & \text { (Human) Hepatitis B Virus } \\ \text { HCC } & - & \text { Hepatocellular Carcinoma } \\ \text { L-dT } & - & \beta \text {-L-2'-deoxythymidine } \\ \text { NNRTIs } & - & \text { Non-Nucleoside Reverse Transcriptase Inhibitors } \\ \text { PEG-IFN } & - & \text { Pegylated Interferon } \alpha-2 a \\ \text { pgRNA } & - & \text { pregenomic RNA } \\ \text { RC } & - & \text { Relaxed Circular } \\ \text { siRNAs } & - & \text { small interfering RNAs } \\ \text { TDF } & - & \text { Tenofovir Disoproxil Fumarate } \\ \text { WHV } & - & \text { Woodchuck Hepatitis Virus } \\ & & \end{array}$

\section{Introduction}

Chronic hepatitis B (CHB) can lead to life-threatening conditions like cirrhosis and hepatocellular carcinoma (HCC). Cirrhosis develops in approximately $20 \%$ of chronically infected patients, subsequently leading to hepatic insufficiency and portal hypertension [1]. Moreover, these patients have a 100-fold higher risk of developing hepatocellular carcinoma than non-carriers [2-4]. Hepatitis B excreted antigen ( $\mathrm{HBeAg}$ ) represents an important marker for $\mathrm{HCC}$, since $\mathrm{HBeAg}$-positive subjects are at highest risk of developing HCC [5]. In late stages of cirrhosis or HCC, liver transplantation is the only option left. Therefore, detection of HBV infection at an early stage and prompt treatment are of crucial importance. Indicators for a sustained virological response are clearance of $\mathrm{HBeAg}$, seroconversion from $\mathrm{HBeAg}$ to corresponding anti-HBe antibodies, and a drop in circulating $\mathrm{HBV}$ DNA below detection level $[1,6]$.

Seven drugs have been licensed by the United States FDA (Food and Drug Administration) for the treatment of CHB: interferon-alpha and pegylated interferon-alpha, three nucleoside analogs (lamivudine, entecavir and telbivudine) and two nucleotide analog prodrugs (adefovir dipivoxil and tenofovir disoproxil fumarate) [7,8]. HBV DNA polymerase is the main target for the nucleoside or nucleotide analogs. Drug combination therapy, as is now (standard care) for the treatment of HIV infections, may in the future also become adopted for the treatment of HBV infections. Various dual or triple drug combinations that have been used, with success, in the treatment of human 
immunodeficiency virus (HIV) infection remain to be explored for their potential in the treatment of chronic hepatitis B. Other strategies whether targeted at the viral DNA polymerase or other molecular events in the HBV replication cycle have been reported, i.e., small interfering RNAs (siRNAs) \{As was shown for many other viruses, siRNAs can be used to inhibit HBV replication in vitro [9-11] and in vivo [12]\}, helioxanthin and related molecules, which inhibit viral nucleic acid and viral protein expression [13,14], heteroaryldihydropyrimidines (HAPs), such as BAY 41-4109 which inhibit nucleocapsid formation [15]; imino sugars (such as N-nonyl-deoxynojirimycin), which were found to suppress woodchuck hepatitis virus (WHV) replication in vivo (woodchucks) through inhibition of protein folding and trafficking [16]; nitazoxanide, tizoxanide and other thiazolides, which inhibit both hepatitis B virus and hepatitis C virus replication [17]; HBF-0259, a tetrahydro-tetrazolo-(1,5-a)-pyrimidine which specifically inhibits HBV surface antigen secretion [18]; $\beta$-LPA, a 2,6-diaminopurine analog containing a structure showing a mode of action that remains to be elucidated [19]; and a series of 7-deazaneplanocin A analogs for which, likewise, the mode of action remains to be elucidated [20]. Efficient inhibition of HBV replication has also been achieved by hammerhead ribozymes delivered by hepatitis delta virus [21].

\section{HBV Replication Cycle}

Three types of particles are produced during replication of HBV: (i) Dane particles (infectious virions) [22], (i) $20 \mathrm{~nm}$ HBsAg (hepatitis B surface antigen) spheres and (iii) variable length $\mathrm{HBsAg}$ filaments [23]. The latter two particles are non-infectious [24-26]. The virions contain a $3.2 \mathrm{~kb}$ relaxed circular (RC) DNA with four overlapping ORFs, namely P, C, S and X. The S gene encodes for three surface proteins: Large, Medium and Small HBsAg [27]. The polymerase is translated from the $\mathrm{P}$ ORF. The polymerase protein consists of four domains: terminal protein, spacer, RT and RNase H [28-30]. Of the seven subdomains of RT, domain C harbors the highly conserved YMDD motif, i.e., the catalytic site of the enzyme [31,32]. Infected hepatocytes also contain the hepatitis B core antigen ( $\mathrm{HBcAg})$. $\mathrm{HBcAg}$, the excreted antigen ( $\mathrm{HBeAg}$ ), is encoded from the ORF $\mathrm{C}$ domain [33,34].

Following interaction with (an) unknown receptor(s), RC DNA from the virion is transported to the nucleus and converted into covalently closed circular DNA (cccDNA), while the nucleocapsids remain in the cytoplasm [35]. This DNA intermediate plays an important role in viral persistence and serves as a template for transcription by host RNA polymerase II to produce four mRNA transcripts of 3.5, 2.4, 2.1 and $0.7 \mathrm{~kb}$ [36]. Importantly, cccDNA may be indicative of risk for HCC development, as Wong et al. have shown that tumor tissues had higher levels of cccDNA compared to non-tumor tissues [37].

During core particle formation, encapsidation of the pgRNA takes place and reverse transcription starts [38]. The polymerase binds at the 5' end of the pgRNA [39,40]. The original RNA template is degraded by RNAse H, except for a small RNA oligomer. Once (-) DNA synthesis is complete, a second translocation (the RNA primer translocation) to the 5' end of DR2 occurs and (+) DNA synthesis starts using (-) DNA as template. Finally, circularization and extension of (variable length) $(+)$ DNA strand terminates the DNA synthesis $[39,40]$. 
In a minority of the virions [41], (+) DNA can either be (i) converted into cccDNA [42,43] or be (ii) integrated into chromosomal DNA [44-46]. The nucleocapsids are enclosed by envelope glycoproteins after budding into the endoplasmic reticulum and Golgi apparatus [47,48]. Mature virions are released through the secretory pathway. Alternatively, nucleocapsids are recycled back to the nucleus to maintain cccDNA levels (a process referred to as recycling pathway) [35]. For a more detailed description of HBV replication and gene function, see Ganem and Schneider [49]. Of all the steps in the HBV replication cycle, the reverse transcription can be considered as the most important target for current anti-HBV chemotherapy.

\section{Currently Approved (Licensed) Anti-HBV Drugs for the Treatment of CHB}

\subsection{Lamivudine}

Lamivudine [(-)ß-L-2',3'-dideoxy-3'-thiacytidine (3TC)] (Figure 1A) has anti-HIV and anti-HBV properties. It was approved in 1998 by the FDA for the treatment of chronic hepatitis B infections. Lamivudine (Epivir-HBV ${ }^{\circledR}$ or Zeffix ${ }^{\circledR}$ ) is administered daily at an oral dose of $100 \mathrm{mg}$. Within the cell, 3TC is converted to its active form [3TC-triphosphate (3TC-TP)] [50]. Subsequently, 3TC-TP can act as (i) a chain terminator, after incorporation into the growing HBV DNA chain, or (i) as a competitive inhibitor of deoxycytidine triphosphate (dCTP) at the level of the DNA polymerase. 3TC-TP inhibits viral DNA synthesis, but not mitochondrial DNA synthesis [51]. Lamivudine may interrupt the recycling of virions to the nucleus and suppress the formation of cccDNA [52].

Lamivudine treatment generally results in a three- to four-log drop in circulating HBV DNA levels, at least during the first months of treatment [53,54], and the HBV DNA levels after four weeks of lamivudine treatment may predict the long-term (five-year) outcome [55]. Concomitantly, $\mathrm{HBeAg}$ is cleared more rapidly from the circulation, and serum alanine aminotransferase (ALT) levels may normalize $[53,54]$. The virological and biochemical response may show a reduction of up to $74 \%$ and $66 \%$, respectively [56]. The drug is usually well tolerated [57,58]. Long-term lamivudine treatment may reduce the risk of developing cirrhosis and HCC [59].

However, lamivudine monotherapy rapidly leads to resistance development. Approximately $20 \%$ of HBeAg-positive patients develop resistance after one year, which increases up to $70 \%$ after five years $[60,61]$ (Figure 2). The most common mutation is observed in the catalytic YMDD motif of the viral RT polymerase. The primary lamivudine-resistance mutation is $\mathrm{M} 204 \mathrm{~V} / \mathrm{I} / \mathrm{S}$ (in the viral RT polymerase) in the highly conserved YMDD motif. This is often combined with the L180M mutation [62] (Table 1). Lamivudine-resistant mutations can also occur outside the YMDD motif [63]. Although lamivudine-resistant HBV mutants remain highly sensitive to adefovir and tenofovir, cross-resistance has been observed towards other L-nucleoside analogs such as emtricitabine and telbivudine [64,65]. 
Figure 1. Currently licensed anti-HBV drugs. (A) The L-nucleoside analog lamivudine; (B) the acyclic nucleoside phosphonate adefovir (PMEA), licensed as its prodrug adefovir dipivoxil [bis(pivaloyloxymethyl)ester of 9-(2-phosphonylmethoxyethyl)adenine or bis(POM)PMEA]; (C) the carbocyclic D-nucleoside analog entecavir; (D) the L-nucleoside analog $\beta$-L-2'-deoxythymidine (L-dT), or telbivudine; and (E) the acyclic nucleoside phosphonate tenofovir, licensed as its prodrug tenofovir disoproxil fumarate (TDF) [bis(isopropoxycarbonyloxymethyl) ester of 9-(R)-2-(phosphonylmethoxypropyl)adenine or bis(POC)PMPA].

(A)<smiles>Nc1ccn(C2CC3OCC2O3)c(=O)n1</smiles>

(B)<smiles>Nc1ncnc2c1ncn2CCOCP(=O)(O)O</smiles><smiles>CC(C)(C)C(=O)OCOP(=O)(COCCn1cnc2c(N)ncnc21)OCOC(=O)C(C)(C)C</smiles>

(C)

(D)<smiles>C=C1C(CO)C(O)CC1n1cnc2c(=O)[nH]c(N)nc21</smiles><smiles>Cc1cn(C2CC(O)C(CO)O2)c(=O)[nH]c1=O</smiles>

(E)<smiles>CC(Cn1cnc2c(N)ncnc21)OCP(=O)(O)O</smiles><smiles>C=C</smiles><smiles></smiles> 
Figure 2. Cumulative incidence of HBV resistance to lamivudine (LAM), adefovir (ADV), entecavir (ETV), telbivudine (LdT) and tenofovir (TDF) in published pivotal trials in NUC-naive patients. For method of calculation, see [61]. These trials included different populations, used different exclusion criteria and different follow-up endpoints [151].

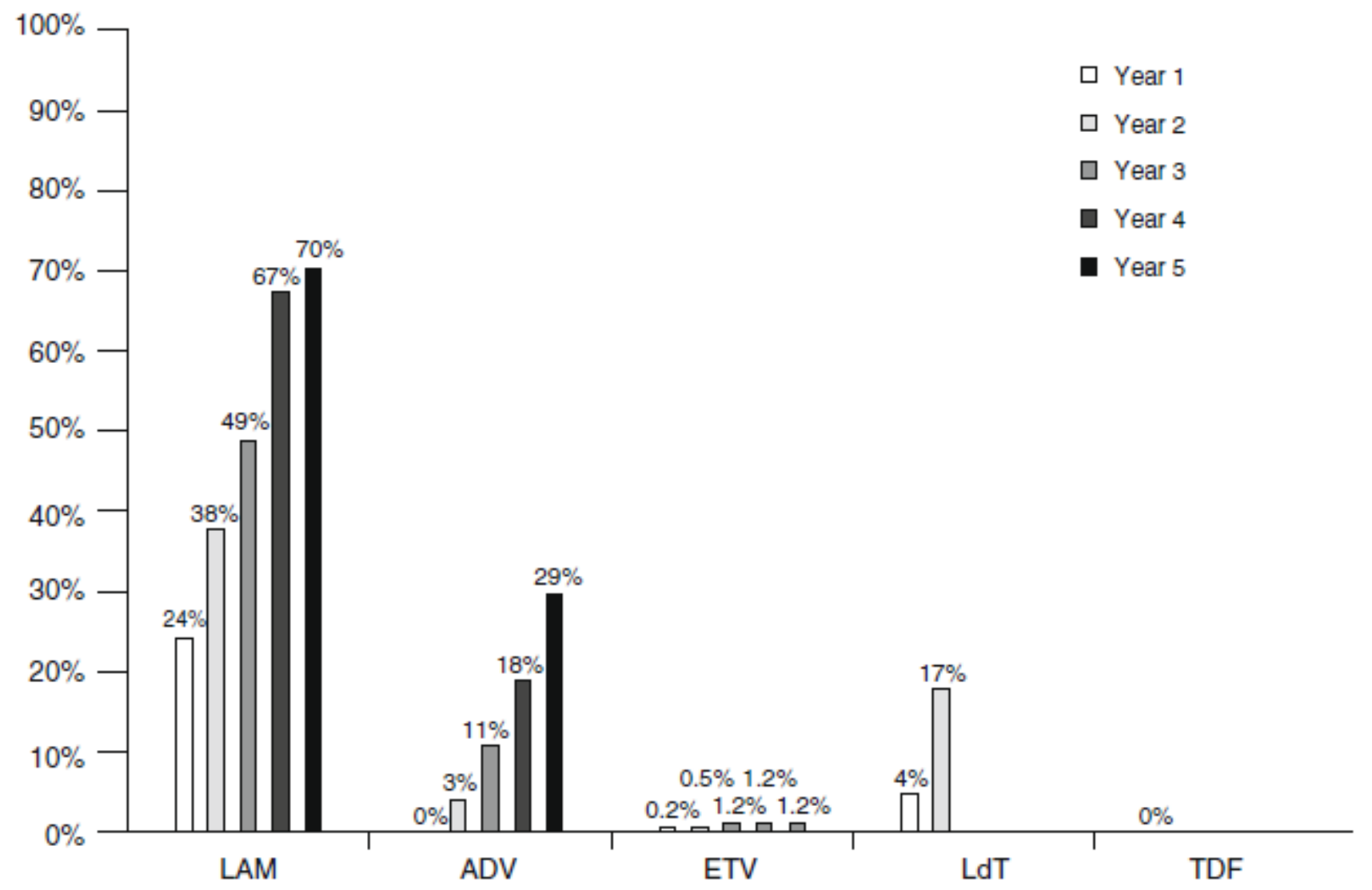

\subsection{Adefovir dipivoxil}

Adefovir (or PMEA [9-(2-phosphonylmethoxyethyl)adenine]) is an acyclic nucleoside phosphonate [66]. To increase its oral availability, PMEA has been esterified to its prodrug bis(POM)PMEA (Figure 1B). Adefovir dipivoxil was licensed as Hepsera ${ }^{\circledR}$ in September 2002 for the treatment of CHB. It is administered orally at a dose of $10 \mathrm{mg}$ daily.

When PMEA enters the cell, it is phosphorylated twice by AMP kinase [67] to its active form PMEApp, which is incorporated into the growing HBV DNA chain, where it acts as (i) an obligatory chain terminator [68] and/or (ii) a competitive inhibitor of the natural substrate dATP. In addition to its anti-HBV activity, PMEApp has also demonstrated activity against other viruses, i.e., herpesviruses and retroviruses as well as bacteria producing adenylate cyclase toxins (e.g., B. anthracis, B. pertussis, P. aeruginosa) [69]. Treatment for 48 weeks with adefovir dipivoxil led to a decrease of both cccDNA and HBsAg levels in HBeAg-positive CHB patients; it has been estimated that it may take approximately 14.5 years to clear infected cells from cccDNA [70]. 
Table 1. Currently licensed anti-HBV drugs as well as anti-HBV agents that are in clinical or preclinical development. Mutations that are/can be selected by these agents are indicated as well as the cross-resistance and sensitivity profiles of the drug-resistant variants.

\begin{tabular}{|c|c|c|c|c|}
\hline Agent & \multicolumn{2}{|c|}{ Mutation(s) } & Cross-resistant to & \multirow{2}{*}{\begin{tabular}{l}
\multicolumn{1}{c}{ Sensitive to } \\
Adefovir, Tenofovir, \\
Entecavir \pm MPA
\end{tabular}} \\
\hline Lamivudine & $\begin{array}{l}\mathrm{rtM} 204 \mathrm{I} / \mathrm{S} / \mathrm{V} \\
\pm \mathrm{rtL} 180 \mathrm{M} \\
\pm \mathrm{rtV} 173 \mathrm{C} \\
\mathrm{rTA} 181 \mathrm{~S} \text { plu } \\
\mathrm{rT} 181 \mathrm{~T}\end{array}$ & ГM204I & $\begin{array}{l}\text { Other L-nucleoside } \\
\text { analogs (Emtricitabine, } \\
\text { Telbivudine) } \\
\text { Adefovir }\end{array}$ & \\
\hline Adefovir & $\mathrm{rtA} 181 \mathrm{~V} / \mathrm{T}$ a & or rtN236T & & $\begin{array}{l}\text { Lamivudine, } \\
\text { Entecavir, } \\
\text { Emtricitabine, } \\
\text { Tenofovir }\end{array}$ \\
\hline Adefovir & $\mathrm{rtI} 233 \mathrm{~V}$ & & & Tenofovir \\
\hline Entecavir & $\left.\begin{array}{l}\mathrm{rtT} 184 \mathrm{G} \text { or } \\
\mathrm{rtS} 202 \mathrm{I} \text { or } \\
\mathrm{rtM} 250 \mathrm{~V}\end{array}\right\}$ & $\begin{array}{l}+ \text { Lamivudine- } \\
\text { resistance } \\
\text { mutations } \\
\end{array}$ & Lamivudine & Adefovir \\
\hline Telbivudine & rtM204I J & & Lamivudine & \\
\hline Tenofovir & $\begin{array}{l}\text { rtA194T + I } \\
\text { mutations (rt }\end{array}$ & $\begin{array}{l}\text { ivudine resistance } \\
04 \mathrm{~V}+\mathrm{rtL} 180 \mathrm{M})\end{array}$ & & \\
\hline Emtricitabine & $\mathrm{rt} 204 \mathrm{I} / \mathrm{V} \pm \mathrm{rt}$ & $30 \mathrm{M}$ and $\mathrm{rtV} 173 \mathrm{C}$ & Lamivudine & \\
\hline
\end{tabular}

Although treatment with $10 \mathrm{mg}$ adefovir dipivoxil for 48 weeks resulted in a good anti-HBV response in $\mathrm{CHB}$ patients who were either negative or positive for $\mathrm{HBeAg}$ [71,72], efficacy was still improved if treatment was extended to 144 weeks in HBeAg-negative patients [73]. Adefovir dipivoxil at a dose of $10 \mathrm{mg}$ /day has very few adverse effects; at higher doses, i.e., 30 or $60 \mathrm{mg} / \mathrm{day}$ (or $125 \mathrm{mg}$ /day as initially used when the compound was developed for HIV treatment), the compound may be nephrotoxic [1,6,72]. Adefovir dipivoxil is being used at a dose as low as $10 \mathrm{mg} /$ day, which may be considered as suboptimal [74]. Adefovir dipivoxil at a dose of $10 \mathrm{mg}$ is well tolerated and had a similar side effect profile as placebo in phase III clinical trials. Nephrotoxicity has been reported in $3 \%$ of patients with compensated liver disease after 4-5 years of continued adefovir dipivoxil therapy and in $6 \%$ of patients on the transplant waiting list $[75,76]$.

The rate of development of adefovir resistance is much lower than for lamivudine monotherapy: not more than $6 \%$ after three years [73], and up to $18 \%$ after four years [77]. After five years of therapy, $29 \%$ of the treated patients harbor adefovir-resistant HBV strains (as compared to $70 \%$ for lamivudine) [78].

Recent re-assessments estimated the cumulative probability of adefovir-resistant mutations at 12 and 24 months to be $5 \%$ and $17 \%$, respectively [79]. The main adefovir resistance is associated with the $\mathrm{rtN} 236 \mathrm{~T}$ and $\mathrm{rtA} 181 \mathrm{~V} / \mathrm{T}$ mutations $[80,81]$. In lamivudine-resistant patients, emergence of the 
$\mathrm{rtN236T}$ and $\mathrm{rtA} 181 \mathrm{~V} / \mathrm{T}$ mutations is more common (Table 1), as compared to nucleoside-naïve patients [82].

Recently, three patients with primary adefovir resistance were described, which remained sensitive to tenofovir. The HBV variant already had a mutation before adefovir therapy was even initiated. When investigated more thoroughly, results showed that an rtI233V mutation was responsible for the adefovir resistance [83]. In general, adefovir-resistant HBV mutants remain susceptible to L-nucleoside analogs (i.e., lamivudine and entecavir) [84]. Adefovir resistance can be associated with viral rebound, hepatic flares and hepatic decompensation [85]. To prevent the emergence of adefovir resistance, adefovir should be combined with lamivudine, even in lamivudine-resistant patients [86]. Adefovir is active against lamivudine-resistant HBV strains (in liver transplant recipients) [76] as well as cirrhotic patients who failed on lamivudine therapy [87].

\subsection{Entecavir}

Entecavir (Figure 1C) has been approved (licensed as Baraclude ${ }^{\circledR}$ ) in the United States for the treatment of $\mathrm{CHB}$ virus infections since April 2005. Its metabolism is comparable with that of the other nucleoside analogs. ETV is phosphorylated three times by human cellular kinases to its active form, ETV-TP. Intracellular accumulation occurs rapidly, its half-life is approximately 15 hours (as for lamivudine) [88] and it interferes with the HBV DNA polymerase in multiple ways: (i) it inhibits the priming of the polymerase, (ii) it has a high affinity for the HBV polymerase, (iii) it acts as a competitive inhibitor of dGTP (natural substrate) and (iv) it acts as a chain terminator two or three nucleotides downstream from its incorporation [89,90]. In fact, the incorporation of entecavir monophosphate into the DNA has at least three consequences: first, incorporation of the next nucleotide at position $\mathrm{n}+1$ following the incorporated entecavir monophosphate is compromised; second, strong pausing at position $\mathrm{n}+3$ suggests a delayed chain termination; and, third, the incorporated entecavir monophosphate can also act as a "base pair confounder" during synthesis of the second DNA strand [91].

Woodchucks chronically infected with woodchuck hepatitis virus (WHV), treated with $0.5 \mathrm{mg} / \mathrm{kg}$ ETV daily for eight weeks, showed decreased viremia levels. Long-term therapy with ETV, once a week, was also effective in maintaining low levels of viral load, decreasing cccDNA levels and viral antigens, expanding the life of the animals, and delaying the onset of HCC [92]. Two double-blind phase III studies with $715 \mathrm{HBeAg}$-positive and $648 \mathrm{HBeAg-negative} \mathrm{nucleoside-naïve} \mathrm{CHB} \mathrm{patients}$ revealed that entecavir therapy led to higher improved histological and virological values (like reduction in viral load, $\mathrm{HBeAg}$ loss and seroconversion) and reduced alanine aminotransferase levels compared with lamivudine $[93,94]$. Entecavir at a dose of $1 \mathrm{mg}$ per day for 96 weeks of treatment resulted in continued clinical benefit in lamivudine-refractory $\mathrm{HBeAg}$-positive $\mathrm{CHB}$ patients [95]. From clinical trials in China [96], Yao concluded that entecavir was superior to lamivudine as an anti-HBV drug [96], although in some instances, it showed only limited efficacy, with a "partial virologic response to adefovir therapy" [97].

For patients with lamivudine failure, higher doses of ETV are recommended, as $10 \%$ of these patients might develop ETV resistance after two years [89]. The approved dose of entecavir for nucleoside-naïve patients is $0.5 \mathrm{mg}$ daily orally and for lamivudine-resistant patients is $1.0 \mathrm{mg}$ daily 
orally. But even at the higher dose $(1.0 \mathrm{mg} /$ day $)$, entecavir is no longer recommended for the treatment of lamivudine-resistant patients due to the high rates of entecavir resistance in such patients.

The following mutations are specifically associated with ETV resistance: rtT184G, rtS202I, and rtM250V (Table 1) [98,99]. Two additional mutations (rtM204V and rTL180M) are associated with resistance to both lamivudine and entecavir (Table 1) [99]. The virologic response is closely related to the genotypic resistance [100], and although a high incidence of the emergence of entecavir-resistant mutants has been described among patients infected with lamivudine-resistant HBV [101], long-term monitoring has shown that entecavir resistance of $\mathrm{HBV}$ in nucleoside-naïve patients is rare through five years of therapy [102], thus proving a high genetic barrier of HBV drug resistance to entecavir.

Surprisingly, in patients co-infected with HBV and HIV-1, entecavir led to the emergence of the lamivudine-resistant HIV-1 M184V reverse transcriptase variant [103,104], which on the one hand cautions against the use of entecavir in persons infected with both HIV-1 and HBV [105], but on the other hand suggests that entecavir may exhibit inhibitory activity against HIV under conditions of reduced viral challenge [106], although the HIV infection has no effect on the pharmacokinetics of entecavir in HBV-infected patients [107].

\subsection{Telbivudine}

Telbivudine (Figure 1D) (for recent reviews see Keam [108] and Nash [109]) offers a new option for the treatment of CHB [110]: the compound is administered orally once daily as a single tablet of $600 \mathrm{mg}$. The L-nucleoside telbivudine ( $\beta$-L-2'-deoxythymidine or L-dT) is a specific anti-HBV agent. The 3'OH group is essential for anti-HBV activity; and removal or substitution of this group results in loss of activity [111]. In vitro studies with HepG2 cells and primary human hepatocytes have shown high phosphorylation rates of L-dT and L-dC [112]. Its active form L-dT-TP prefers to inhibit $(+)$-strand DNA synthesis and acts as a chain terminator [113]. It should be pointed out, however, that telbivudine, containing a 3'-hydroxyl function, does not have to act as an obligatory chain terminator.

Data from phase I and phase II clinical trials have shown that different doses of telbivudine result in considerable reductions in HBV DNA levels after four weeks of treatment. Upon withdrawal of telbivudine the viral load dramatically increased [114]. A one year trial has shown that telbivudine decreased HBV DNA levels with $>6 \log _{10}$ compared with lamivudine ( $\left.4.5 \log _{10}\right)$ [115]. In HBeAg-positive, compensated CHB patients, L-dT gave an HBV DNA reduction of $6.30 \log _{10}$ (44 patients) after 24 weeks as compared to $4.97 \log _{10}$ for adefovir dipivoxil (89 patients) [116].

As compared to lamivudine, telbivudine demonstrated greater HBV DNA suppression in both HBeAg-negative and HBeAg-positive CHB patients [117]. Likewise, in Chinese patients with CHB, telbivudine, upon a year of treatment, provided greater antiviral and clinical efficacy than lamivudine [118]. During telbivudine treatment, non detectable serum HBV DNA after 24 weeks is the strongest predictor for optimal outcomes after two years [119].

The mutation rtM204I has been observed in patients who received telbivudine [115]. Data from Yang et al. showed that lamivudine-resistant strains are cross-resistant with several L-nucleosides, such as L-dT, L-dC and emtricitabine (Table 1) [64]. Therefore, telbivudine cannot be used to treat patients with lamivudine-resistant HBV. The phase III GLOBE trial showed that telbivudine, compared with lamivudine in $\mathrm{HBeAg}$ - positive and -negative patients, resulted in a higher antiviral and 
clinical efficacy after two years of treatment [120]. From a pharmacokinetic point of view, telbivudine could, in principle, be combined with lamivudine or adefovir, because no drug interactions were observed [121].

Against HBV genomes with known telbivudine-resistance mutations, M204I and L80I/M204I, telbivudine, lamivudine and entecavir lost 353- to >1000-fold activity, whereas adefovir and tenofovir exhibited no more than a 3- to 5-fold decrease in activity [122].

\subsection{INF- $\alpha$}

INF- $\alpha$ was the first substance licensed to treat $\mathrm{CHB}$ virus infections. Only $30 \%$ of the patients showed a successful response with loss of HBeAg, HBV DNA and normalization of ALT levels. Influenza-like side effects were observed. The mechanism of action of interferon is two-fold [123]: (i) it elicits antiviral activity (e.g., induction of 2',5'-oligoadenylate synthetase), as well as (ii) immunomodulatory activity (e.g., increased expression of MHC I, and stimulation of CTLs). The recommended regimen of interferon $\alpha$ is $5 \times 10^{6}$ units administered daily or $102 \times 10^{6}$ units given three times a week subcutaneously for a period of four to six months [124]. At present, two types of interferon have been approved for CHB treatment: interferon $\alpha-2 b$ (Intron A; Schering-Plough) and pegylated interferon $\alpha-2 \mathrm{a}$ (PEG-IFN; Pegasys; Roche).

During 48 weeks, 814 patients with HBeAg-positive CHB received PEG-IFN plus placebo, PEGIFN plus lamivudine, or lamivudine alone, and were followed up for 24 weeks. This study demonstrated that PEG-IFN - with or without lamivudine treatment - led to higher percentages of HBeAg seroconversion, HBV DNA suppression and HBsAg seroconversion (this was not observed with lamivudine monotherapy) and, thus, PEG-IFN $2 \alpha$ provides a significant improved efficiency over lamivudine [125]. In the HBeAg-negative CHB patients, PEG-IFN $\alpha$-2a may offer a sustained response, resulting in $\mathrm{HBsAg}$ clearance three years after treatment [126].

PEG-IFN $\alpha-2 b$ is effective against HBeAg-positive CHB, but combinations with lamivudine [127] or ribavirin [128] resulted in no additional benefit. In contrast, a recent combination treatment study in CHB patients by Wursthorn et al., using PEG-IFN $\alpha-2 b$ and adefovir, showed a strong reduction in HBV DNA, cccDNA and HBsAg levels [129]. Peginterferon $\alpha-2 b$ has been shown to be safe and effective in HBeAg-positive CHB patients with advanced fibrosis, and, hence, these patients should not be excluded from PEG-IFN treatment [130].

\subsection{Tenofovir disoproxil fumarate}

Tenofovir disoproxil fumarate (TDF) $\left(\right.$ Viread $^{\circledR}$ ) (Figure 1E) was approved by the FDA for the treatment of AIDS in 2001 and for the treatment of CHB in 2008. The efficacy of TDF against wild-type as well as lamivudine-resistant HBV strains [131] was demonstrated in patients co-infected with HIV and HBV. In vitro studies revealed that the combination of tenofovir with emtricitabine resulted in additive to synergistic effect. Combinations with lamivudine, entecavir or telbivudine resulted in additive effects [132]. Tenofovir undergoes two efficient phosphorylations to its active form, PMPApp, which has a long half-life (95 h) [133]. It functions as a chain terminator and represents a poor substrate for cellular DNA polymerases $\alpha, \beta$ and $\varepsilon[134,135]$. To increase oral 
absorption, tenofovir is esterified to its bis(isopropyloxycarbonyloxymethyl)ester [tenofovir disoproxil, bis(POC)PMPA] (Figure 1E).

At a daily dose of $300 \mathrm{mg}$ it has a superior antiviral efficacy (with a similar safety profile), as compared with adefovir dipivoxil at a daily dose of $10 \mathrm{mg}$, following 48 weeks of treatment [136]. Several studies have corroborated that TDF is more potent than adefovir dipivoxil in the treatment of CHB [137-140]. TDF is highly efficacious in the treatment of advanced liver disease in patients co-infected with HBV and HIV who developed resistance to lamivudine [141]. Woodchuck studies using different concentrations of TDF administered once a day for four weeks showed a good safety profile and reductions in viremia levels [142].

The rtA194T mutation in vitro and in HBV/HIV co-infected patients showed TDF resistance in the presence of lamivudine mutations rtL180M and rtM204V (Table 1) [143]. The rTA194T polymerase mutations are associated with partial tenofovir resistance and negatively impacts replication competence of HBV constructs. Viral replication, however, can be restored to wild-type levels, if these polymerase mutations occur together with precore or basic core promoter substitutions as found in HBeAg-negative hepatitis B [144]. Patients with HBeAg-negative chronic HBV infection may therefore be at particular risk when developing resistance to tenofovir. TDF offers an important alternative for patients with low lamivudine or adefovir dipivoxil responses [145].

\section{Novel anti-HBV agents}

\subsection{Emtricitabine}

Emtricitabine or (-)FTC has been licensed for the treatment of HIV infections. The mechanism of action is similar to that of lamivudine. Following three phosphorylations, (-)FTC acts as (i) a chain terminator for the nascent HBV DNA chain and/or (ii) as a competitive inhibitor of its natural substrate dCTP. Additionally, (-)FTC-TP is a weak inhibitor of cellular and mitochondrial DNA polymerases. At different doses, emtricitabine, when given to chronically WHV-infected woodchucks, caused reduced viremia levels [146].

Studies in humans have shown that $200 \mathrm{mg}$ (-)FTC (the optimal dose) daily for two years gave a safe antiviral profile but a resistance rate of $18 \%$ [147] (versus $20 \%$ for lamivudine after one year). The (-)FTC resistance mutations observed were $\mathrm{rtM} 204 \mathrm{I} / \mathrm{V} \pm \mathrm{rtL} 180 \mathrm{M}$ and $\mathrm{rtV} 173 \mathrm{~L}$ (Table 1). A study comparing the combination of the standard dose (-)FTC and $10 \mathrm{mg}$ clevudine and (-)FTC alone for 24 weeks showed no significant difference between both groups, but the combination group had a significantly greater virological and biochemical response at 24 weeks post-treatment. The prolonged anti-HBV activity of clevudine was also observed in the combination group, as well as in phase II clinical trials where clevudine monotherapy was administered [148,149]. Possible side effects observed with (-)FTC include lactic acidosis and hepatoxicity [150]. In addition, flare-ups of HBV infection after withdrawal of (-)FTC have also been reported [150].

\subsection{Clevudine}

Clevudine corresponds to L-FMAU (2'-fluoro-5-methyl- $\beta$-L-arabinofuranosyluracil). Serum HBV DNA levels were undetectable by PCR at the end of treatment in 59\% of $\mathrm{HBe}$ Ag-positive and in $92 \%$ 
of $\mathrm{HBe}$ Ag-negative patients [151,152]. A unique feature of clevudine is the durability of viral suppression, persisting for up to 24 weeks after withdrawal of treatment. Nonetheless, clevudine has not been shown to increase the rate of $\mathrm{HBe} \mathrm{Ag}$ seronconversion compared to placebo controls. Clinical trials found that the rtA181T mutation, which is associated with resistance to lamivudine and adefovir could be selected after only 24 weeks of clevudine treatment [151]. Clevudine was then reported to be associated with myopathy in patients who had been treated for longer than 24 weeks, and mitochondrial toxicity was documented in some patients $[153,154]$. These observations have led to the discontinuation of the global phase III clinical trials with clevudine.

\section{Recommendations}

Clinical practice guidelines for the management of chronic hepatitis B have been published by the European Association for the Study of the Liver (EASL) [155], the American Association for the Study of Liver Diseases (AASLD) [156] and the Asian Pacific Association for the Study of the Liver (APASL) [157,158]; the latter being specific for the immunomodulatory therapy of CHB.

Rates of HBe seroconversion, undetectable HBV DNA and normal ALT at one year of therapy with (pegylated) interferon, lamivudine, adefovir dipivoxil, entecavir, telbivudine and tenofovir disoproxil fumarate in $\mathrm{HBe} \mathrm{Ag}$-positive patients are presented in Figure 3A, and those of undetectable $\mathrm{HBV}$ DNA and normal ALT in HBe Ag-negative patients are presented in Figure 3B (both sets of data taken from [155]). The most potent drugs, i.e., tenofovir or entecavir, should be used as first-line monotherapies [155].

Rates of resistance at up to five years of treatment are shown in Figure 2. Resistance is associated with prior treatment with lamivudine, adefovir, telbivudine or emtricitabine. Resistance should be identified as early as possible before clinical breakthrough (increased ALT) by means of HBV DNA monitoring, and, if possible, identification of the resistance mutations. Clinical and virological studies have demonstrated the benefit of an early treatment adaptation as soon as viral load increases $[159,160]$.

Table 2 shows cross-resistance data for the most frequent drug-resistant HBV variants [161]. Although the long-term safety of the indicated combination is unknown, it is recommended [155] to (i) in the case of lamivudine resistance, to add tenofovir (or adefovir if tenofovir is not available); (ii) in the case of adefovir resistance, to switch to tenofovir (if available; or if an N236T mutation is present, to add lamivudine, entecavir or telbivudine, or if an A181T/V mutation is present, to add

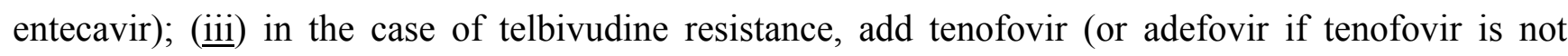
available); (v) resistance to tenofovir has not been described so far $[61,155]$.

The APASL [157] guidelines stipulated that for patients who develop lamivudine resistance, add-on adefovir therapy is indicated, and that for lamivudine-naïve patients who develop drug resistance while on adefovir, add-on or switching to lamivudine, telbivudine or entecavir is indicated, while for patients who develop drug resistance while on telbivudine, add-on adefovir therapy is indicated [157]. 
Figure 3. (A) Rates of HBe seroconversion, undetectable HBV DNA and normal ALT at one year of therapy with pegylated interferon alpha-2a (PEG-IFN), lamivudine (LAM), adefovir (ADV), entecavir (ETV), telbivudine (LdT) and tenofovir (TDF) in HBeAgpositive patients with $\mathrm{CHB}$ in randomized clinical trials. (B) Rates of undetectable HBV DNA and normal ALT at one year of therapy with PEG-IFN, LAM, ADV, ETV, LdT and TDF in HBeAg-negative patients with CHB in randomized clinical trials. The trials in (A) and (B) used different HBV DNA assays and they were not head-to-head comparisons for all the drugs; thus, these numbers are only indicative and should be considered with caution [155].

A.
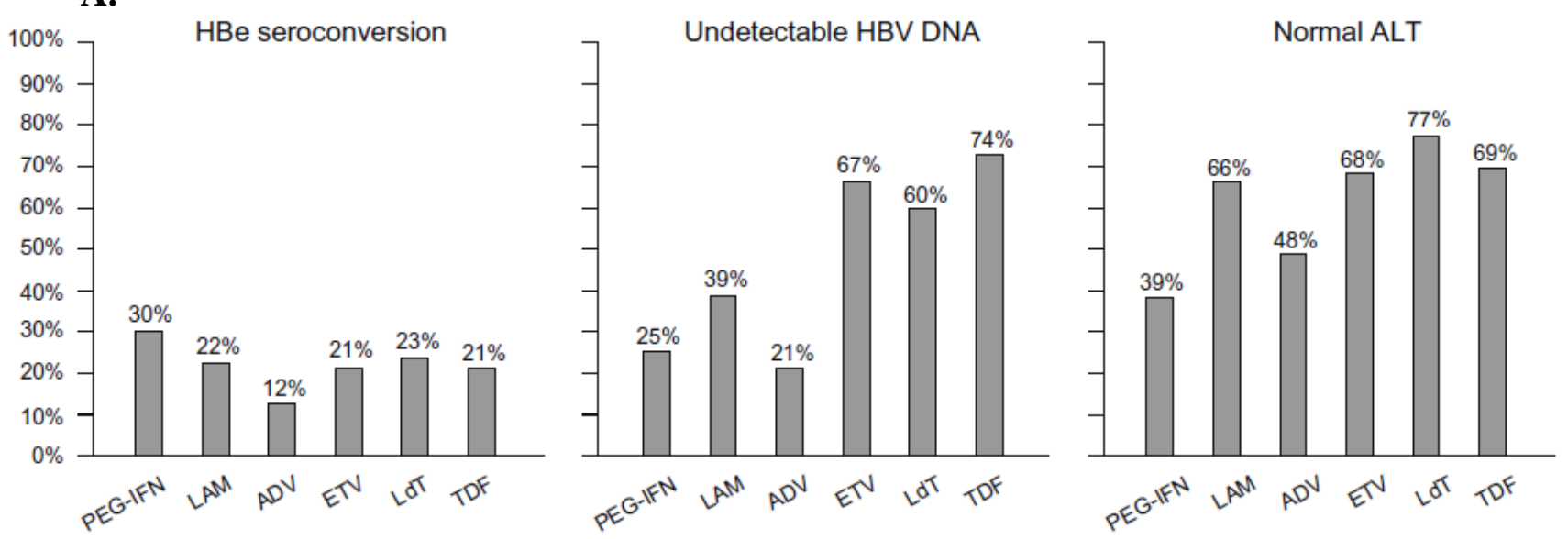

B.
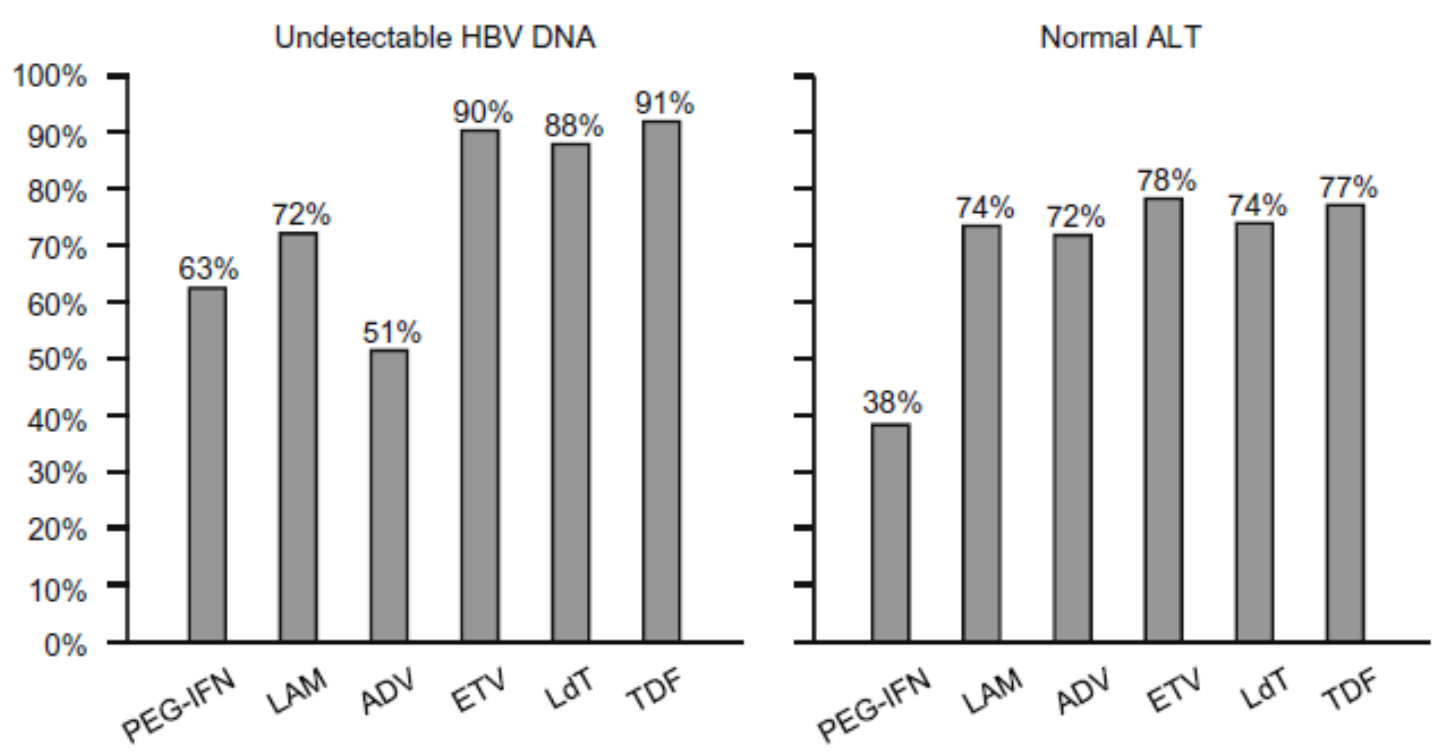
Table 2. Cross-resistance data for the most frequently resistant HBV variants. The amino-acid substitution profiles are shown in the left column and the level of susceptibility is given for each drug: S (sensitive), I (intermediate/reduced susceptibility), R (resistant) [161].

\begin{tabular}{lccccc}
\hline HBV variant & \multicolumn{5}{c}{ Level of susceptibility } \\
\cline { 2 - 6 } & Lamivudine & Telbivudine & Entecavir & Adefovir & Tenofovir \\
\hline Wild-type & $\mathrm{S}$ & $\mathrm{S}$ & $\mathrm{S}$ & $\mathrm{S}$ & $\mathrm{S}$ \\
M204I & $\mathrm{R}$ & $\mathrm{R}$ & $\mathrm{I}$ & $\mathrm{S}$ & $\mathrm{S}$ \\
$\mathrm{L} 180 \mathrm{M}+\mathrm{M} 204 \mathrm{~V}$ & $\mathrm{R}$ & $\mathrm{R}$ & $\mathrm{I}$ & $\mathrm{S}$ & $\mathrm{S}$ \\
$\mathrm{A} 181 \mathrm{~T} / \mathrm{V}$ & $\mathrm{I}$ & $\mathrm{S}$ & $\mathrm{S}$ & $\mathrm{R}$ & $\mathrm{S}$ \\
$\mathrm{N} 236 \mathrm{~T}$ & $\mathrm{~S}$ & $\mathrm{~S}$ & $\mathrm{~S}$ & $\mathrm{R}$ & $\mathrm{I}$ \\
$\mathrm{L} 180 \mathrm{M}+\mathrm{M} 204 \mathrm{I} / \mathrm{S} / \mathrm{V} \pm$ & $\mathrm{R}$ & $\mathrm{R}$ & $\mathrm{R}$ & $\mathrm{S}$ & $\mathrm{S}$ \\
$\mathrm{I} 169 \mathrm{~T} \pm \mathrm{V} 173 \mathrm{~L} \pm \mathrm{M} 250 \mathrm{~V}$ & & & & & \\
$\mathrm{~L} 180 \mathrm{M}+\mathrm{M} 204 \mathrm{I} / \mathrm{S} / \mathrm{V} \pm$ & $\mathrm{R}$ & $\mathrm{R}$ & $\mathrm{R}$ & $\mathrm{S}$ & $\mathrm{S}$ \\
$\mathrm{T} 184 \mathrm{G} \pm \mathrm{S} 202 \mathrm{I} / \mathrm{G}$ & & & & & \\
\hline
\end{tabular}

\section{Concluding Remarks}

Besides interferon, five licensed products are currently available for the treatment of chronic HBV

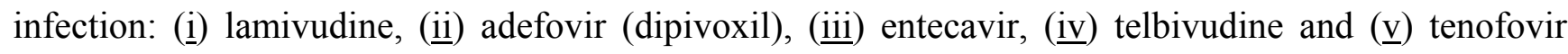
(disoproxil fumarate) (see Table 3). Lamivudine monotherapy is associated with higher resistance (up to $70 \%$ after five years) than adefovir (29\% after five years) or telbivudine (9-22\% after two years) [162].

Table 3. Anti-HBV agents.

\begin{tabular}{llll}
\hline Generic name & Brand name & Manufacturer & Date of FDA approval \\
\hline \multicolumn{2}{l}{ Anti-HBV drugs approved by the US Food and Drug Administration } & \\
Interferon alfa-2b & Intron A & Schering-Plough & 13 July 1992 \\
Lamivudine, 3TC & Epivir-HBV & GlaxoSmithKline & 9 December 1998 \\
Adefovir dipivoxil & Hepsera & Gilead Sciences & 20 September 2002 \\
Entecavir & Baraclude & Bristol-Myers Squibb & 30 March 2005 \\
Peginterferon alfa-2a & Pegasys & Roche & 13 May 2005 \\
Telbivudine & Tyzeka & Idenix & 25 October 2006 \\
Tenofovir disoproxil fumarate & Viread & Gilead Sciences & 11 August 2008 \\
\hline
\end{tabular}

Entecavir resistance is rare in naïve individuals ( $<1 \%$ after four years), but increases over time in lamivudine-resistant patients (43\% after four years). According to Papatheodoridis et al. [162], the 
best strategy for long-term therapy in chronic HBV infection has yet to be established. This paper was published on 8 March 2008 before TDF was formally licensed for use in the treatment of CHB. Entecavir and tenofovir may represent the drugs of choice for the treatment of CHB as they couple high potency with a high genetic barrier [163], but entecavir monotherapy certainly is not the treatment of choice for lamivudine-resistant HBV patients [150].

Cross-trial comparisons of treatment outcomes, comparing pegylated interferon $\alpha-2 \mathrm{a}$, lamivudine (LAM), adefovir (ADV) dipivoxil, entecavir (ETV), telbivudine (LDT) and tenofovir disoproxil fumarate (TDF) in terms of three parameters, (i) HBV DNA reduction, (ii) HBeAg seroconversion and (iii) rate of resistance have indicated that ETV and TDF (both as monotherapy) are superior to the other treatment regimens (also as monotherapy) [164]. In the near future, improvements in HBV therapy will likely involve combinations of potent nucleoside analogs (such as entecavir or telbivudine) with a potent nucleotide such as tenofovir. In the longer term future HBV therapy may or should aim at achieving a gain in post-treatment durable response rates by the development of HBV drugs with a novel mechanism of action (such as for example encapsidation inhibitors) or immunomodulatory approaches, that can be used in combination with nucleos(t)ides.

\section{Acknowledgments}

The original work of the authors was supported by the VIRGIL European Network of Excellence on Antiviral Drug Resistance supported by a grant (LSHM-CT-2004-503359) from the Priority 1 "Life Sciences, Genomics and Biotechnology for Health" and is supported by a grant from the FWO (no. G.0267.04). The proficient help of Christiane Callebaut is acknowledged with the sincerest gratitude.

\section{References and Notes}

1. Ganem, D; Prince, A.M. Hepatitis B virus infection - Natural history and clinical consequences. N. Engl. J. Med. 2004, 350, 1118-1129.

2. Beasley, R.P. Hepatitis B virus: the major etiology of hepatocellular carcinoma. Cancer 1988, 61, 1942-1956.

3. Chiaramonte, M.; Stroffolini, T.; Vian, A.; Stazi, M.A.; Floreani, A.; Lorenzoni, U.; Lobello, S.; Farinati, F.; Naccarato, R. Rate of incidence of hepatocellular carcinoma in patients with compensated viral cirrhosis. Cancer 1999, 85, 2132-2137.

4. Fattovich, G.; Pantalena, M.; Zagni, I.; Realdi, G.; Schalm, S.W.; Christensen, E. Effect of hepatitis B and C virus infections on the natural history of compensated cirrhosis: a cohort study of 297 patients. Am. J. Gastroenterol. 2002, 97, 2886-2895.

5. Yang, H.I.; Lu, S.N.; Liaw, Y.F.; You, S.L.; Sun, C.A.; Wang, L.Y.; Hsiao, C.K.; Chen, P.J.; Chen, D.S.; Chen, C.J. Hepatitis B e antigen and the risk of hepatocellular carcinoma. N. Engl. J. Med. 2002, 347, 168-174.

6. Zoulim, F. Antiviral therapy of chronic hepatitis B. Antiviral Res. 2006, 71, 206-215.

7. Keeffe, E.B.; Marcellin, P. New and emerging treatment of chronic hepatitis B. Clin. Gastroenterol. Hepatol. 2007, 5, 285-294.

8. Palumbo, E. New drugs for chronic hepatitis B: a review. Am. J. Therapeut. 2008, 15, 167-172. 
9. Peng, J.; Zhao, Y.; Mai, J.; Pang, W.K.; Wei, X.; Zhang, P.; Xu, Y. Inhibition of hepatitis B virus replication by various RNAi constructs and their pharmacodynamic properties. J. Gen. Virol. 2005, 86, 3227-3234.

10. Ying, C.; De Clercq, E.; Neyts, J. Selective inhibition of hepatitis B virus replication by RNA interference. Biochem. Biophys. Res. Commun. 2003, 309, 482-484.

11. Chen, Y.; Cheng, G., Mahato, R.I. RNAi for treating hepatitis B viral infection. Pharm. Res. 2008, 25, 72-86.

12. McCaffrey, A.P.; Nakai, H.; Pandey, K.; Huang, Z.; Salazar, F.H.; Xu, H.; Wieland, S.F.; Marion, P.I.; Kay, M.A. Inhibition of hepatitis B virus in mice by RNA interference. Nat. Biotechnol. 2003, 21, 639-644.

13. Cheng, Y.C.; Ying, C.X.; Leung, C.H.; Li, Y. New targets and inhibitors of HBV replication to combat drug resistance. J. Clin. Virol. 2005, 34 Suppl. 1, S147-S150.

14. Ying, C.; Li, Y.; Leung, C.H.; Robek, M.D. Cheng, Y.C. Unique antiviral mechanism discovered in anti-hepatitis B virus research with a natural product analogue. Proc. Natl. Acad. Sci. USA 2007, 104, 8526-8531.

15. Deres, K.; Schröder, C.H.; Paessens, A.; Goldmann, S.; Hacker, H.J.; Weber, O.; Krämer, T.; Niewöhner, U.; Pleiss, U.; Stoltefuss, J.; Graef, E.; Koletzki, D.; Masantschek, R.N.; Reimann, A.; Jaeger, R.; Gross, R.; Beckermann, B.; Schlemmer, K.H.; Haebich, D.; Rübsamen-Waigmann, $\mathrm{H}$. Inhibition of hepatitis B virus replication by drug-induced depletion of nucleocapsids. Science 2003, 299, 893-896.

16. Block, T.M.; Lu, X.; Mehta, A.S.; Blumberg, B.S.; Tennant, B.; Ebling, M.; Korba, B.; Lansky, D.M.; Jacob, G.S., Dwek, R.A. Treatment of chronic hepadnavirus infection in a woodchuck animal model with an inhibitor of protein folding and trafficking. Nat. Med. 1998, 4, 610-614.

17. Korba, B.E.; Montero, A.B.; Farrar, K.; Gaye, K.; Mukerjee, S.; Ayers, M.S.; Rossignol, J.F. Nitazoxanide, tizoxanide and other thiazolides are potent inhibitors of hepatitis $\mathrm{B}$ virus and hepatitis C virus replication. Antiviral Res. 2008, 77, 56-63.

18. Dougherty, A.M.; Guo, H.; Westby, G.; Liu, Y.; Simsek, E.; Guo, J.T.; Mehta, A.; Norton, P.; Gu, B.; Block, T.; Cuconati, A. A substituted tetrahydro-tetrazolo-pyrimidine is a specific and novel inhibitor of hepatitis B virus surface antigen secretion. Antimicrob. Agents Chemother. 2007, 51, 4427-4437.

19. He, X.X.; Chen, T.; Lin, J.S.; Chang, Y.; Ye, B.X. Inhibition of the replication of hepatitis B virus in vitro by a novel 2,6-diaminopurine analog, beta-LPA. Biochem. Biophys. Res. Commun. 2008, 369, 513-518.

20. Kim, H.J.; Sharon, A.; Bal, C.; Wang, J.; Allu, M.; Huang, Z.; Murray, M.G.; Bassit, L.; Schinazi, R.F.; Korba, B.; Chu, C.K. Synthesis and anti-hepatitis B virus and anti-hepatitis C virus activities of 7-deazaneplanocin A analogues in vitro. J. Med. Chem. 2009, 52, 206-218.

21. Li, X.; Kuang, E.; Dai, W.; Zhou, B.; Yang, F. Efficient inhibition of hepatitis B virus replication by hammerhead ribozymes delivered by hepatitis delta virus. Virus. Res. 2005, 114, 126-132.

22. Dane, D.S.; Cameron, C.H.; Briggs, M. Virus-like particles in serum of patients with Australiaantigen-associated hepatitis. Lancet 1970, 1, 695-698.

23. Robinson, W.S.; Lutwick, L.I. The virus of hepatitis, type B (first of two parts). N. Engl. J. Med. 1976, 295, 1168-1175. 
24. Gavilanes, F.; Gonzalez-Ros, J.M.; Peterson, D.L. Structure of hepatitis B surface antigen: Characterization of the lipid components and their association with the viral proteins. J. Biol. Chem. 1982, 257, 7770-7777.

25. Peterson, D.L. Isolation and characterization of the major protein and glycoprotein of hepatitis B surface antigen. J. Biol. Chem. 1981, 256, 6975-6983.

26. Peterson, D.L. The structure of hepatitis B surface antigen and its antigenic sites. Bioessays 1987, 6, 258-262.

27. Valenzuela, P.; Gray, P.; Quiroga, M.; Zaldivar, J.; Goodman, H.M.; Rutter, W.J. Nucleotide sequence of the gene coding for the major protein of hepatitis B virus surface antigen. Nature 1979, 280, 815-819.

28. Bartenschlager, R.; Schaller, H. The amino-terminal domain of the hepadnaviral P-gene encodes the terminal protein (genome linked protein) believed to prime reverse transcription. EMBO J. 1988, 7, 4185-4192.

29. Chang, L.J.; Hirsch, R.C.; Ganem, D.; Varmus, H.E. Effects of insertional and point mutations on the functions of the duck hepatitis B virus polymerase. J. Virol. 1990, 11, 5553-5558.

30. Radziwill, G.; Tucker, W.; Schaller, H. Mutational analysis of the hepatitis B virus P gene product: domain structure and RNase H activity. J. Virol. 1990, 2, 613-620.

31. Poch, O.; Sauvaget, I.; Delarue, M.; Tordo, N. Identification of four conserved motifs among the RNA-dependent polymerase encoding elements. EMBO J. 1989, 8, 3867-3874.

32. Tipples, G.A.; Ma, M.M.; Fischer, K.P.; Bain, V.G.; Kneteman, N.M.; Tyrrell, D.L.J. Mutation in HBV RNA-dependent DNA polymerase confers resistant to lamivudine in vivo. Hepatology 1996, 24, 714-717.

33. Ou, J.H.; Laub, O.; Rutter, W.J. Hepatitis B virus gene function: the pre-core region targets the core antigen to cellular membranes and causes the secretion of the e entigen. Proc. Natl. Acad. Sci. USA 1986, 83, 1578-1582.

34. Pasek, M.; Goto, T.; Gilbert, W.; Zink, B.; Schaller, H.; MacKay, P.; Leadbetter, G.; Murray, K. Hepatitis B virus genes and their expression in E. coli. Nature 1979, 282, 575-579.

35. Tuttleman, J.S.; Pourcel, C.; Summers, J. Formation of the pool of covalently closed circular viral DNA in hepadnavirus-infected cells. Cell 1986, 47, 451-460.

36. Will, H.; Reiser, W.; Weimer, T.; Pfaff, E.; Büscher, M.; Sprengel, R.; Cattaneo, R.; Schaller, H. Replication strategy of human hepatitis B virus. J. Virol. 1987, 61, 904-911.

37. Wong, D.K.; Yuen, M.F.; Poon, R.T.; Yuen, J.C.; Fung, J.; Lai, C.L. Quantification of hepatitis B virus covalently closed circular DNA in patients with hepatocellular carcinoma. J. Hepatol. 2006, 45, 553-559.

38. Pollack, J.R.; Ganem, D. Site-specific RNA binding by a hepatitis B virus reverse transcriptase initiates two distinct reactions: RNA packaging and DNA synthesis. J. Virol. 1994, 68, 5579-5587.

39. Hu, J.; Seeger, C. Hsp90 is required for the activity of a hepatitis B virus reverse transcriptase. Proc. Natl. Acad. Sci. USA 1996, 93, 1060-1064.

40. Seeger, C.; Mason, W.S. Hepatitis B virus biology. Microbiol. Mol. Biol. Rev. 2000, 64, 51-68. 
41. Staprans, S.; Loeb, D.D.; Ganem, D. Mutations affecting hepadnavirus plus-strand DNA synthesis dissociate primer cleavage from translocation and reveal the origin of linear viral DNA. J. Virol. 1991, 65, 1255-1262.

42. Yang, W.; Mason, W.S.; Summers, J. Covalently closed circular viral DNA formed from two types of linear DNA in woodchuck hepatitis virus-infected liver. J. Virol. 1996, 70, 4567-4575.

43. Yang, W.; Summers, J. Illegitimate replication of linear hepadnavirus DNA through nonhomologous recombination. J. Virol. 1995, 69, 4029-4036.

44. Yang, W.; Summers J. Integration of hepadnavirus DNA in infected liver: evidence for a linear precursor. J. Virol. 1999, 73, 9710-9717.

45. Gong, S.S.; Jensen, A.D.; Chang, C.J.; Rogler, C.E. Double-stranded linear duck hepatitis B virus (DHBV) stably integrates at a higher frequency than wild-type DHBV in LMH chicken hepatoma cells. J. Virol. 1999, 73, 1492-1502.

46. Gong, S.S.; Jensen, A.D.; Wang, H.; Rogler, C.E. Duck hepatitis B virus integrations in LMH chicken hepatoma cells: identification and characterization of new episomally derived integrations. J. Virol. 1995, 69, 8102-8108.

47. Kamimura, T.; Yoshikawa, A.; Ichida, F.; Sasaki, H. Electron microscopic studies of Dane particles in hepatocytes with special reference to intracellular development of Dane particles and their relation with HBeAg in serum. Hepatology 1981, 1, 392-397.

48. Roingeard, P.; Lu, S.L.; Sureau, C.; Freschlin, M.; Arbeille, B.; Essex, M.; Romet-Lemonne, J.L. Immunocytochemical and electron microscopic study of hepatitis B virus antigen and complete particle production in hepatitis B virus DNA transfected HepG2 cells. Hepatology 1990, 11, 277-285.

49. Ganem, D.; Schneider, R.J. Hepadnaviridae: The viruses and their replication. In Fields Virology, 4th edition. Lippincott Williams \& Wilkins: Philadelphia, PA, USA, 2001; pp. 2923-2969.

50. Cammack, N.; Rouse, P.; Marr, C.L.; Reid, P.J.; Boehme, R.E.; Coates, J.A.; Penn, C.R.; Cameron, J.M. Cellular metabolism of (-) enantiomeric 2'-deoxy-3'-thiacytidine. Biochem. Pharmacol. 1992, 43, 2059-2064.

51. Chang, C.N.; Skalski, V.; Zhou, J.H.; Cheng, Y.C. Biochemical pharmacology of (+)- and (-)2',3'-dideoxy-3'-thiacytidine as anti-hepatitis B virus agents. J. Biol. Chem. 1992, 267, 22414-22420.

52. Lai, C.L.; Yuen, M.F. Profound suppression of hepatitis B virus replication with lamivudine. J. Med. Virol. 2000, 61, 367-373.

53. Dienstag, J.L.; Schiff, E.R.; Wright, T.L.; Perrillo, R.P.; Hann, H.W.; Goodman, Z.; Crowther, L.; Condreay, L.D.; Woessner, M.; Rubin, M.; Brown, N.A . Lamivudine as initial treatment for chronic hepatitis B in the United States. N. Engl. J. Med. 1999, 341, 1256-1263.

54. Lai, C.L.; Chine, R.W.; Leung, N.W.Y.; Chang, T.T.; Guan, R.; Tai, D.I.; Ng, K.Y.; Wu, P.C.; Dent, J.C.; Barber, J.; Stephenson, S.L.; Gray, F. A one year trial of lamivudine for chronic hepatitis B. N. Engl. J. Med. 1998, 339, 61-68.

55. Yuen, M.F.; Fong, D.Y.; Wong, D.K.; Yuen, J.C.; Fung, J.; Lai, C.L. Hepatitis B virus DNA levels at week 4 of lamivudine treatment predict the 5-year ideal response. Hepatology 2007, 46, 1695-1703. 
56. Fung, S.K.; Wong, F.; Hussain, M.; Lok, A.S.F. Sustained response after a 2-year course of lamivudine treatment of hepatitis B e antigen-negative chronic hepatitis B. J. Viral. Hepatol. 2004, 11, 432-438.

57. Perry, C.M.; Faulds, D. Lamivudine. A review of its antiviral activity, pharmacokinetic properties and therapeutic efficacy in the management of HIV infection. Drugs 1997, 53, 657-680.

58. Schalm, S.W.; Heathcote, J.; Cianciara, J.; Farrell, G.; Sherman, M.; Willems, B.; Dhillon, A.; Moorat, A.; Barber; J.; Gray, D.F. Lamivudine and alpha interferon combination treatment of patients with chronic hepatitis B infection: a randomised trial. Gut 2000, 46, 562-568.

59. Yuen, M.F.; Seto, W.K.; Chow, D.H.; Tsui, K.; Wong, D.K.; Ngai, V.W.; Wong, B.C.; Fung, J.; Yuen, J.C.; Lai, C.L. Long-term lamivudine therapy reduces the risk of long-term complications of chronic hepatitis B infection even in patients without advanced disease. Antiviral Ther. 2007, 12, 1295-1303.

60. Lok, A.S.; Lai, C.L.; Leung, N.; Yao, G.B.; Cui, Z.Y.; Schiff, E.R.; Dienstag, J.L.; Heathcote, E.J.; Little, N.R.; Griffiths, D.A.; Gardner, S.D.; Castiglia, M. Long-term safety of lamivudine treatment in patients with chronic hepatitis B. Gastroenterology 2003, 125, 1714-1722.

61. Pawlotsky, J.M.; Dusheiko, G.; Hatzakis, A.; Lau, D.; Lau, G.; Liang, T.J.; Locarnini, S.; Martin, P.; Richman, D.D.; Zoulim, F. Virologic monitoring of hepatitis B virus therapy in clinical trials and practice: recommendations for a standardized approach. Gastroenterology 2008, 134, 405-415.

62. Das, K.; Xiong, X.; Yang, H.; Westland, C.E.; Gibbs, C.S.; Sarafianos, S.G.; Arnold, E. Molecular modeling and biochemical characterization reveal the mechanism of hepatitis B virus polymerase resistance to lamivudine (3TC) and emtricitabine (FTC). J. Virol. 2001, 75, 4771-4779.

63. Yatsuji, H.; Noguchi, C.; Hiraga, N.; Mori, N.; Tsuge, M.; Imamura, M.; Takahashi, S.; Iwao, E.; Fujimoto, Y.; Ochi, H.; Abe, H.; Maekawa, T.; Tateno, C.; Yoshizato, K.; Suzuki, F.; Kumada, H.; Chayama, K. Emergence of a novel lamivudine-resistant hepatitis B virus variant with a substitution outside the YMDD motif. Antimicrob. Agents Chemother. 2006, 50, 3867-3874.

64. Yang, H.; Qi, X.; Sabogal, A.; Miller, M.; Xiong, S.; Delaney, W.E. Cross-resistance testing of next-generation nucleoside and nucleotide analogues against lamivudine-resistant HBV. Antiviral Ther. 2005, 10, 625-633.

65. Karatayli, E.; Karayalçin, S.; Karaaslan, H.; Kayhan, H.; Türkyilmaz, A.R.; Sahin, F.; Yurdaydin, C.; Bozdayi, A.M. A novel mutation pattern emerging during lamivudine treatment shows crossresistance to adefovir dipivoxil treatment. Antiviral Ther. 2007, 12, 761-768.

66. De Clercq, E.; Holý A.; Rosenberg, I.; Sakuma, T.; Balzarini, J.; Maudgal, P.C. A novel selective broad-spectrum anti-DNA virus agent. Nature 1986, 323, 464-467.

67. Merta, A.; Votruba, I.; Jindrich, J.; Holý, A.; Cihlár, T.; Rosenberg, I.; Otmar, M.; Herve, T.Y. Phosphorylation of 9-(2-phosphonomethoxyethyl)adenine and 9-(S)-(3-hydroxy-2phosphonomethoxypropyl)adenine by AMP(dAMP) kinase from L1210 cells. Biochem. Pharmacol. 1992, 44, 2067-2077.

68. De Clercq, E. Antivirals and antiviral strategies. Nat. Rev. Microbiol. 2004, 2, 704-720. 
69. Shen, Y.; Zhukovskaya, N.L.; Zimmer, M.I.; Soelaiman, S.; Bergson, P.; Wang, C.R.; Gibbs, C.S.; Tang, W.J. Selective inhibition of anthrax edema factor by adefovir, a drug for chronic hepatitis B virus infection. Proc. Natl. Acad. Sci. U S A 2004, 101, 3242-3247.

70. Werle-Lapostolle, B.; Bowden, S.; Locarnini, S.; Wursthorn, K.; Petersen, J.; Lau, G.; Trepo, C.; Marcellin, P.; Goodman, Z.; Delaney, W.E. 4th; Xiong, S.; Brosgart, C.L.; Chen, S.S.; Gibbs,. CS.; Zoulim, F. Persistence of cccDNA during the natural history of chronic hepatitis B and decline during adefovir dipivoxil therapy. Gastroenterology 2004, 126, 1750-1758.

71. Hadziyannis, S.J.; Tassopoulos, N.C.; Heathcote, E.J.; Chang, T.T.; Kitis, G.; Rizzetto, M.; Marcellin, P.; Lim, S.G.; Goodman, Z.; Wulfsohn, M.S.; Xiong, S.; Fry, J.; Brosgart, C.L. Adefovir dipivoxil for the treatment of hepatitis B e antigen-negative chronic hepatitis B. N. Engl. J. Med. 2003, 348, 800-807.

72. Marcellin, P.; Chang, T.T.; Lim, S.G.; Tong, M.J.; Sievert, W.; Shiffman, M.L.; Jeffers, L.; Goodman, Z.; Wulfsohn, M.S.; Xiong, S.; Fry, J.; Brosgart, C.L. Adefovir dipivoxil 437 study group. Adefovir dipivoxil for the treatment of hepatitis B e antigen-positive chronic hepatitis B. N. Engl. J. Med. 2003, 348, 848-850.

73. Hadziyannis, S.J.; Tassopoulos, N.C.; Heathcote, E.J.; Chang, T.T.; Kitis, G.; Rizzetto, M.; Marcellin, P.; Lim, S.G.; Goodman, Z.; Ma, J.; Arterburn, S.; Xiong, S.; Currie, G.; Brosgart, C.L. Long-term therapy with adefovir dipivoxil for HBeAg-negative chronic hepatitis B. N. Engl. J. Med. 2005, 352, 2673-2681.

74. Carrouée-Durantel, S.; Durantel, D.; Werle-Lapostolle, B.; Pichoud, C.; Naesens, L.; Neyts, J.; Trépo, C.; Zoulim, F. Suboptimal response to adefovir dipivoxil therapy for chronic hepatitis B in nucleoside-naive patients is not due to pre-existing drug-resistant mutants. Antiviral Ther. 2008, 13, 381-388.

75. Hadziyannis, S.J.; Tassopoulos, N.C.; Heathcote, E.J.; Chang, T.T.; Kitis, G.; Rizzetto, M.; Marcellin, P.; Lim, S.G.; Goodman, Z.; Ma,J.; Brosgart, C.L.; Borroto-Esoda, K.; Arterburn, S.; Chuck, S.L.; Adefovir Dipivoxil 438 Study Group. Long-term therapy with adefovir dipivoxil for HBeAg-negative chronic hepatitis B for up to 5 years. Gastroenterology 2006, 131, 1743 1751.

76. Schiff, E.; Lai, C.L.; Hadziyannis, S.; Neuhaus, P.; Terrault, N.; Colombo, M.; Tillmann, H.; Samuel, D.; Zeuzem, S.; Villeneuve, J.P.; Arterburn, S.; Borroto-Esoda, K.; Brosgart, C.; Chuck, S. Adefovir dipivoxil for wait-listed and post-liver transplantation patients with lamivudine-resistant hepatitis B: final long-term results. Liver Transpl. 2007, 13, 349-360.

77. Marcellin, P.; Asselah, T. Resistance to adefovir: a new challenge in the treatment of chronic hepatitis B. J. Hepatol. 2005, 43, 920-923.

78. Borroto-Esoda, K.; Miller, M.D.; Arterburn, S. Pooled analysis of amino acid changes in the HBV polymerase in patients from four major adefovir dipivoxil clinical trials. J. Hepatol. 2007, 47, 492-498

79. Gallego, A.; Sheldon, J.; García-Samaniego, J.; Margall, N.; Romero, M.; Hornillos, P.; Soriano, V.; Enríquez, J. Evaluation of initial virological response to adefovir and development of adefovir-resistant mutations in patients with chronic hepatitis B. J. Viral Hepat. 2008, 15, 392-398. 
80. Lacombe, K.; Ollivet, A.; Gozlan, J.; Durantel, S.; Tran, N.; Girard, P.M.; Zoulim, F. A novel hepatitis $\mathrm{B}$ virus mutation with resistance to adefovir but not to tenofovir in an HIV-hepatitis B virus-co-infected patient. AIDS 2006, 20, 2229-2231.

81. Osiowy, C.; Villeneuve, J.P.; Heathcote, E.J.; Giles, E.; Borlang, J. Detection of rtN236T and rtA181V/T mutations associated with resistance to adefovir dipivoxil in samples from patients with chronic hepatitis B virus infection by the INNO-LiPA HBV DR Line Probe Assay (version 2). J. Clin. Microbiol. 2006, 44, 1994-1997.

82. Lee, Y.S.; Suh, D.J.; Lim, Y.S.; Jung, S.W.; Kim, K.M.; Lee, H.C.; Chung, Y.H.; Lee, Y.S.; Yoo, W.; Kim, S.O. Increased risk of adefovir resistance in patients with lamivudine-resistant chronic hepatitis B after 48 weeks of adefovir dipivoxil monotherapy. Hepatology 2006, 43, 1385-1391.

83. Schildgen, O.; Sirma, H.; Funk, A.; Olotu, C.; Wend, U.C.; Hartmann, H.; Helm, M.; Rockstroh, J.K.; Willems, W.R.; Will, H.; Gerlich, W.H. Variant of hepatitis B virus with primary resistance to adefovir. N. Engl. J. Med. 2006, 354, 1807-1812.

84. Villeneuve, J.P.; Durantel, D.; Durantel, S.; Westland, C.; Xiong, S.; Brosgart, C.L.; Gibbs, C.S.; Parvaz, P.; Werle, B.; Trépo, C.; Zoulim, F. Selection of a hepatitis B virus strain resistant to adefovir in a liver transplantation patient. J. Hepatol. 2003, 39, 1085-1089.

85. Fung, S.K.; Andreone, P.; Han, S.H.; Reddy, K.R.; Regev, A.; Keeffe, E.B.; Hussain, M.; Cursaro, C.; Richtmyer, P.; Marrero, J.A.; Lok, A.S.F. Adefovir-resistant hepatitis B can be associated with viral rebound and hepatic decompensation. J. Hepatol. 2005, 43, 937-943.

86. Fung, S.K.; Chae, H.B.; Fontana, R.J.; Conjeevaral, H.; Marrero, J.; Oberhelman, K.; Hussain, M.; Lok, A.S.F. Virologic response and resistance to adefovir in patients with chronic hepatitis B. J. Hepatol. 2006, 44, 283-290.

87. Zoulim F, Parvaz P, Marcellin P, Zarski JP, Beaugrand M, Benhamou Y, Bailly F, Maynard M, Trepo C, Trylesinski A, Monchecourt F. Adefovir dipivoxil is effective for the treatment of cirrhotic patients with lamivudine failure. Liver Int. 2009, 29, 420-426.

88. Yamanaka, G.; Wilson, T.; Innaimo, S.; Bisacchi, G.S.; Egli, P.; Rinehart, J.K.; Zahler, R.; Colonno, R.J. Metabolic studies on BMS-200475, a new antiviral compound active against hepatitis B virus. Antimicrob. Agents Chemother. 1999, 43, 190-193.

89. Zoulim, F. Entecavir: a new treatment option for chronic hepatitis B. J. Clin. Virol. 2006, 36, 8-12.

90. Seifer, M.; Hamatake, R.K.; Colonno, R.J.; Standring, D.N. In vitro inhibition of hepadnavirus polymerases by the triphosphates of BMS-200475 and lobucavir. Antimicrob. Agents Chemother. 1998, 42, 3200-3208.

91. Tchesnokov, E.P.; Obikhod, A.; Schinazi, R.F.; Götte, M. Delayed chain termination protects the anti-hepatitis B virus drug entecavir from excision by HIV-1 reverse transcriptase. J. Biol. Chem. 2008, 283, 34218-34228.

92. Colonno, R.J.; Genovesi, E.V.; Medina, I.; Lamb, L.; Durham, S.K.; Huang, M.L.; Corey, L.; Littlejohn, M.; Locarnini, S.; Tennant, B.C.; Rose, B.; Clark, J.M. Long-term entecavir treatment results in sustained antiviral efficacy and prolonged life span in the woodchuck model of chronic hepatitis infection. J. Infect. Dis. 2001, 184, 1236-1245.

93. Chang, T.T.; Gish, R.G.; de Man, R.; Gadano, A.; Sollano, J.; Chao, Y.C.; Lok, A.S.; Han, K.H.; Goodman, Z.; Zhu, J.; Cross, A.; DeHertogh, D.; Wilber, R.; Colonno, R.; Apelian, D. A 
comparison of entecavir and lamivudine for HBeAg-positive chronic hepatitis B. N. Engl. J. Med. 2006, 354, 1001-1010.

94. Lai, C.L.; Shouval, D.; Lok, A.S.; Chang, T.T.; Cheinquer, H.; Goodman, Z.; DeHertogh, D.; Wilber, R.; Zink, R.C.; Cross, A.; Colonno, R.; Fernandes, L. Entecavir versus lamivudine for patients with HBeAg-negative chronic hepatitis B. N. Engl. J. Med. 2006, 354, 1011-1020.

95. Sherman, M.; Yurdaydin, C.; Simsek, H.; Silva, M.; Liaw, Y.F.; Rustgi, V.K.; Sette, H.; Tsai, N.; Tenney, D.J.; Vaughan, J.; Kreter, B.; Hindes, R. Entecavir therapy for lamivudine-refractory chronic hepatitis B: improved virologic, biochemical, and serology outcomes through 96 weeks. Hepatology 2008, 48, 99-108.

96. Yao, G. Entecavir is a potent anti-HBV drug superior to lamivudine: experience from clinical trials in China. J. Antimicrob. Chemother. 2007, 60, 201-205.

97. Reijnders, J.G.P., Pas, S.D., Schutten, M., de Man, R.A., Janssen, H.L.A. Entecavir shows limited efficacy in HBeAg-positive hepatitis B patients with a partial virologic response to adefovir therapy. J. Hepatol. 2009, 50, 674-683.

98. Tenney, D.J.; Levine, S.M.; Rose, R.E.; Walsh, A.W.; Weinheimer, S.P.; Discotto, L.; Plym, M.; Pokornowski, K.; Yu, C.F.; Angus, P.; Ayres, A.; Bartholomeusz, A.; Sievert, W.; Thompson, G.; Warner, N.; Locarnini, S.; Colonno, R.J. Clinical emergence of entecavir-resistant hepatitis B virus requires additional substitutions in virus already resistant to lamivudine. Antimicrob. Agents Chemother. 2004, 48, 3498-3507.

99. Baldick CJ, Tenney DJ, Mazzucco CE, Eggers BJ, Rose RE, Pokornowski KA, Yu CF, Colonno RJ. Comprehensive evaluation of hepatitis B virus reverse transcriptase substitutions associated with entecavir resistance. Hepatology 2008, 47, 1473-1482.

100. Baldick, C.J., Eggers, B.J., Fang, J., Levine, S.M., Pokornowski, K.A., Rose, R.E., Yu, C.-F., Tenney, D.J., Colonno, R.J. Hepatitis B virus quasispecies susceptibility to entecavir confirms the relationship between genotypic resistance and patient virologic response. J. Hepatol. 2008, 48, 895-902.

101. Nagasaki, F.; Niitsuma, H.; Ueno, Y.; Inoue, J.; Kogure, T.; Fukushima, K.; Shimosegawa, T. The high incidence of the emergence of entecavir-resistant mutants among patients infected with lamivudine-resistant hepatitis B virus. Tohoku J. Exp. Med. 2007, 213, 181-186.

102. Tenney, D.J.; Rose, R.E.; Baldick, C.J.; Pokornowski, K.A.; Eggers, B.J.; Fang, J.; Wichroski, M.J.; Xu, D.; Yang, J.; Wilber, R.B.; Colonno, R.J. Long-term monitoring shows hepatitis B virus resistance to entecavir in nucleoside-naïve patients is rare through 5 years of therapy. Hepatology 2009, 49, 1503-1514.

103. McMahon, M.A.; Jilek, B.L.; Brennan, T.P.; Shen, L.; Zhou, Y.; Wind-Rotolo, M.; Xing, S.; Bhat, S.; Hale, B.; Hegarty, R.; Chong, C.R.; Liu, J.O.; Siliciano, R.F.; Thio, C.L. The HBV drug entecavir - effects on HIV-1 replication and resistance. N. Engl. J. Med. 2007, 356, 26142621.

104. Jain, M.K.; Zoellner, C.L. Entecavir can select for M184V of HIV-1: a case of an HIV/hepatitis B (HBV) naïve patient treated for chronic HBV. AIDS 2007, 21, 2365-2366.

105. Sasadeusz, J. The anti-HIV antiviral activity of entecavir: the loss of a trusted friend? J. Hepatol. 2007, 47, 872-874. 
106. Lin, P.F.; Nowicka-Sans, B.; Terry, B.; Zhang, S.; Wang, C.; Fan, L.; Dicker, I.; Gali, V.; Higley, H.; Parkin, N.; Tenney, D.; Krystal, M.; Colonno, R. Entecavir exhibits inhibitory activity against human immunodeficiency virus under conditions of reduced viral challenge. Antimicrob. Agents Chemother. 2008, 52, 1759-1767.

107. Zhu M, Bifano M, Xu X, Wang Y, LaCreta F, Grasela D, Pfister M. Lack of an effect of human immunodeficiency virus coinfection on the pharmacokinetics of entecavir in hepatitis B virusinfected patients. Antimicrob. Agents Chemother. 2008, 52, 2836-2841.

108. Keam, S.J. Telbivudine. Drugs 2007, 67, 1917-1929.

109. Nash, K. Telbivudine in the treatment of chronic hepatitis B. Adv. Ther. 2009, 26, 155-169.

110. Ruiz-Sancho, A.; Sheldon, J.; Soriano, V. Telbivudine: a new option for the treatment of chronic hepatitis B. Exp. Opin. Biol. Ther. 2007, 7, 751-761.

111. Bryant, M.L.; Bridges, E.G.; Placidi, L.; Faraj, A.; Loi, A.G.; Pierra, C.; Dukhan, D.; Gosselin, G.; Imbach, J.L.; Hernandez, B.; Juodawlkis, A.; Tennant, B.; Korba, B.; Cote, P.; Marion, P.; Cretton-Scott, E.; Schinazi, R.F.; Sommadossi, J.P. Antiviral L-nucleosides specific for hepatitis B virus infection. Antimicrob Agents Chemother 2001, 45, 229-235.

112. Hernandez-Santiago, B.; Placidi, L.; Cretton-Scott, E.; Faraj, A.; Bridges, E.G.; Bryant, M.L.; Rodriguez-Orengo, J.; Imbach, J.L.; Gosselin, G.; Pierra, C.; Dukhan, D.; Sommadossi, J.P. Pharmacology of beta-L-thymidine and beta-L-2'-deoxycytidine in HepG2 cells and primary human hepatocytes: relevance to chemotherapeutic efficacy against hepatitis B virus. Antimicrob Agents Chemother 2002, 46, 1728-1733.

113. Kim, J.W.; Park, S.H.; Louie, S.G. Telbivudine: A novel nucleoside analog for chronic hepatitis B. Ann Pharmacother 2006, 40, 472-478.

114. Lai, C.L.; Lim, S.G.; Brown, N.A.; Zhou, X.J.; Lloyd, D.M.; Lee, Y.M.; Yuen, M.F.; Chao, G.C.; Myers, M.W. A dose-finding study of once-daily oral telbivudine in HBeAg-positive patients with chronic hepatitis B virus infection. Hepatology 2004, 40, 719-726.

115. Lai, C.L.; Leung, N.; Teo, E.K.; Tong, M.; Wong, F.; Hann, H.W.; Han, S.; Poynard, T.; Myers, M.; Chao, G.; Lloyd, D.; Brown, N.A. A 1-year trial of telbivudine, lamivudine, and the combination in patients with hepatitis B e antigen-positive chronic hepatitis B. Gastroenterology 2005, 129, 528-536.

116. Chan, H.L.; Heathcote, E.J.; Marcellin, P.; Lai, C.L.; Cho, M.; Moon, Y.M.; Chao, Y.C.; Myers, R.P.; Minuk, G.Y.; Jeffers, L.; Sievert, W.; Bzowej, N.; Harb, G.; Kaiser, R.; Qiao, X.J.; Brown, N.A. Treatment of hepatitis B e antigen positive chronic hepatitis with telbivudine or adefovir: a randomized trial. Ann. Intern. Med. 2007, 147, 745-754.

117. Lai, C.L.; Gane, E.; Liaw, Y.F.; Hsu, C.W.; Thongsawat, S.; Wang, Y.; Chen, Y.; Heathcote, E.J.; Rasenack, J.; Bzowej, N.; Naoumov, N.V.; Di Bisceglie, A.M.; Zeuzem, S.; Moon, Y.M.; Goodman, Z.; Chao, G.; Constance, B.F.; Brown, N.A. Telbivudine versus lamivudine in patients with chronic hepatitis B. N. Engl. J. Med. 2007, 357, 2576-2588.

118. Hou, J.; Yin, Y.K.; Xu, D.; Tan, D.; Niu, J.; Zhou, X.; Wang, Y.; Zhu, L.; He, Y.; Ren, H.; Wan, M.; Chen, C.; Wu, S.; Chen, Y.; Xu, J.; Wang, Q.; Wei, L.; Chao, G.; Constance, B.F.; Harb, G.; Brown, N.A.; Jia, J. Telbivudine versus lamivudine in Chinese patients with chronic hepatitis B: Results at 1 year of a randomized, double-blind trial. Hepatology 2008, 47, 447-454. 
119. Zeuzem, S.; Gane, E.; Liaw, Y.F.; Lim, S.G.; DiBisceglie, A.; Buti, M.; Chutaputti, A.; Rasenack, J.; Hou, J.; O'Brien, C.; Nguyen, T.T.; Jia, J.; Poynard, T.; Belanger, B.; Bao, W.; Naoumov, N.V. Baseline characteristics and early on-treatment response predict the outcomes of 2 years of telbivudine treatment of chronic hepatitis B. J. Hepatol. 2009, 51, 11-20.

120. Liaw, Y.F.; Gane, E.; Leung, N.; Zeuzem, S.; Wang, Y.; Lai, C.L.; Heathcote, E.J.; Manns, M.; Bzowej, N.; Niu, J.; Han, S.H.; Hwang, S.G.; Cakaloglu, Y.; Tong, M.J.; Papatheodoridis, G.; Chen, Y.; Brown, N.A.; Albanis, E.; Galil, K.; Naoumov, N.V. 2-Year GLOBE trial results: telbivudine Is superior to lamivudine in patients with chronic hepatitis B. Gastroenterology 2009, 136, 486-495.

121. Zhou, X.J.; Fielman, B.A.; Lloyd, D.M.; Chao, G.C.; Brown, N.A. Pharmacokinetics of telbivudine in healthy subjects and absence of drug interaction with lamivudine or adefovir dipivoxil. Antimicrob. Agents Chemother. 2006, 50, 2309-2315.

122. Seifer, M.; Patty, A.; Serra, I.; Li, B.; Standring, D.N. Telbivudine, a nucleoside analog inhibitor of HBV polymerase, has a different in vitro cross-resistance profile than the nucleotide analog inhibitors adefovir and tenofovir. Antiviral Res. 2009, 81, 147-155.

123. Thomas, H.; Foster, G.; Platis, D. Mechanisms of action of interferon and nucleoside analogues. J. Hepatol. 2003, 39, S1, S93-98.

124. Lok, A.S.F.; McMahon, B.J. Chronic hepatitis B. Hepatology 2007, 45, 507-539.

125. Lau, G.K.; Piratvisuth, T.; Luo, K.X.; Marcellin, P.; Thongsawat, S.; Cooksley, G.; Gane, E.; Fried, M.W.; Chow, W.C.; Paik, S.W.; Chang, W.Y.; Berg, T.; Flisiak, R.; McCloud, P.; Pluck, N. Peginterferon Alfa-2a, lamivudine, and the combination for HBeAg-positive chronic hepatitis B. N. Engl. J. Med. 2005, 352, 2682-2695.

126. Brunetto, M.R.; Moriconi, F.; Bonino, F.; Lau, G.K.; Farci, P.; Yurdaydin, C.; Piratvisuth, T.; Luo, K.; Wang, Y.; Hadziyannis, S.; Wolf, E.; McCloud, P.; Batrla, R.; Marcellin, P. Hepatitis $\mathrm{B}$ virus surface antigen levels: a guide to sustained response to peginterferon alfa-2a in $\mathrm{HBeAg}$ negative chronic hepatitis B. Hepatology 2009, 49, 1141-1150.

127. Janssen, H.L.; van Zonneveld, M.; Senturk, H.; Zeuzem, S.; Akarca, U.S.; Cakaloglu, Y.; Simon, C.; So, T.M.; Gerken, G.; de Man, R.A.; Niesters, H.G, Zondervan, P.; Hansen, B.; Schalm, S.W. Pegylated interferon alpha-2b alone or in combination with lamivudine for HBeAg-positive chronic hepatitis B: a randomised trial. Lancet 2005, 365, 123-129.

128. Liu, C.J.; Lai, M.Y.; Chao, Y.C.; Liao, L.Y.; Yang, S.S, Hsiao TJ, Hsieh TY, Lin CL, Hu JT, Chen CL, Chen PJ, Kao JH, Chen DS. Interferon alpha-2b with and without ribavirin in the treatment of hepatitis B e antigen-positive chronic hepatitis B: a randomized study. Hepatology 2006, 43, 742-749.

129. Wursthorn, K.; Lutgehetmann, M.; Dandri, M.; Volz, T.; Buggisch, P.; Zollner, B.; Longerich, T.; Schirmacher, P.; Metzler, F.; Zankel, M.; Fischer, C.; Currie, G.; Brosgart, C.; Petersen, J. Peginterferon alpha-2b plus adefovir induce strong cccDNA decline and HBsAg reduction in patients with chronic hepatitis B. Hepatology 2006, 44, 675-684.

130. Buster, E.H.; Hansen, B.E.; Buti, M.; Delwaide, J.; Niederau, C.; Michielsen, P.P.; Flisiak, R.; Zondervan, P.E.; Schalm, S.W.; Janssen, H.L. Peginterferon alpha-2b is safe and effective in HBeAg-positive chronic hepatitis B patients with advanced fibrosis. Hepatology 2007, 46, 388-394. 
131. Benhamou, Y.; Fleury, H.; Trimoulet, P.; Pellegrin, I.; Urbinelli, R.; Katlama, C.; Rozenbaum, W.; Le Teuff, G.; Trylesinski, A.; Piketty, C. Anti-hepatitis B virus efficacy of tenofovir disoproxil fumarate in HIV-infected patients. Hepatology 2006, 43, 548-555.

132.Zhu; Y.; Curtis, M.; Qi, X.; Miller, M.D.; Borroto-Esoda, K. Anti-hepatitis B virus activity in vitro of combinations of tenofovir with nucleoside/nucleotide analogues. Antiviral Chem. Chemother. 2009, 19, 165-176.

133. Delaney, W.E. 4th; Ray, A.S.; Yang, H.; Qi, X.; Xiong, S.; Zhu, Y.; Miller, M.D. Intracellular metabolism and in vitro activity of tenofovir against hepatitis B virus. Antimicrob. Agents Chemother. 2006, 50, 2471-2477.

134. Birkus, G.; Hajek, M.; Kramata, P.; Votruba, I.; Holý, A.; Otova, B. Tenofovir diphosphate is a poor substrate and a weak inhibitor of rat DNA polymerases alpha, delta, and epsilon*. Antimicrob. Agents Chemother. 2002, 46, 1610-1613.

135. Delaney, W.E. 4th; Borroto-Esoda, K. Therapy of chronic hepatitis B: trends and developments. Curr. Opin. Pharmacol. 2008, 8, 532-540.

136. Marcellin, P.; Heathcote, E.J.; Buti, M.; Gane, E.; de Man, R.A.; Krastev, Z.; Germanidis, G.; Lee, S.S.; Flisiak, R.; Kaita, K.; Manns, M.; Kotzev, I.; Tchernev, K.; Buggisch, P.; Weilert, F.; Kurdas, O.O.; Shiffman, M.L.; Trinh, H.; Washington, M.K.; Sorbel, J.; Anderson, J.; SnowLampart, A.; Mondou, E.; Quinn, J.; Rousseau, F. Tenofovir disoproxil fumarate versus adefovir dipivoxil for chronic hepatitis B. N. Engl. J. Med. 2008, 359, 2442-2455.

137. Lacombe, K.; Gozlan, J.; Boyd, A.; Boelle, P.Y.; Bonnard, P.; Molina, J.M.; Miailhes, P.; Lascoux-Combe, C.; Serfaty, L.; Zoulim, F.; Girard, P.M. Comparison of the antiviral activity of adefovir and tenofovir on hepatitis B virus in HIV-HBV-coinfected patients. Antiviral Ther. 2008, 13, 705-713.

138. Del Poggio, P.; Zaccanelli, M.; Oggionni, M.; Colombo, S.; Jamoletti, C.; Puhalo, V. Low-dose tenofovir is more potent than adefovir and is effective in controlling $\mathrm{HBV}$ viremia in chronic HBeAg-negative hepatitis B. World J. Gastroenterol. 2007, 13, 4096-4099.

139. Tan, J.; Degertekin, B.; Wong, S.N.; Husain, M.; Oberhelman, K.; Lok, A.S. Tenofovir monotherapy is effective in hepatitis B patients with antiviral treatment failure to adefovir in the absence of adefovir-resistant mutations. J. Hepatol. 2008, 48, 391-398.

140. Leemans, W.F.; Janssen, H.L.; Niesters, H.G.; de Man, R.A. Switching patients with lamivudine resistant chronic hepatitis B virus from tenofovir to adefovir results in less potent HBV-DNA suppression. J. Viral Hepat. 2008, 15, 108-114.

141. Gutiérrez, S.; Guillemi, S.; Jahnke, N.; Montessori, V.; Harrigan, P.R.; Montaner, J.S. Tenofovirbased rescue therapy for advanced liver disease in 6 patients coinfected with HIV and hepatitis B virus and receiving lamivudine. Clin. Infect. Dis. 2008, 46, e28-30.

142. Menne, S.; Cote, P.J.; Korba, B.E.; Butler, S.D.; George, A.L.; Tochkov, I.A.; Delaney, W.E. 4th; Xiong, S.; Gerin, J.L.; Tennant, B.C. Antiviral effect of oral administration of tenofovir disoproxil fumarate in woodchucks with chronic woodchuck hepatitis virus infection. Antimicrob. Agents Chemother. 2005, 49, 2720-2728.

143. Sheldon, J.; Camino, N.; Rodés, B.; Bartholomeusz, A.; Kuiper, M.; Tacke, F.; Núñez, M.; Mauss, S.; Lutz, T.; Klausen, G.; Locarnini, S.; Soriano, V. Selection of hepatitis B virus 
polymerase mutations in HIV-coinfected patients treated with tenofovir. Antiviral Ther. 2005, 10, 727-734.

144. Amini-Bavil-Olyaee, S.; Herbers, U.; Sheldon, J.; Luedde, T.; Trautwein, C.; Tacke, F. The rtA194T polymerase mutation impacts viral replication and susceptibility to tenofovir in hepatitis B e antigen-positive and hepatitis B e antigen-negative hepatitis B virus strains. Hepatology 2009, 49, 1158-1165.

145. van Bömmel, F.; Zöllner, B.; Sarrazin, C.; Spengler, U.; Hüppe, D.; Möller, B.; Feucht, H.H.; Wiedenmann, B.; Berg, T. Tenofovir for patients with lamivudine-resistant hepatitis B virus (HBV) infection and high HBV DNA level during adefovir therapy. Hepatology 2006, 44, 318-325.

146. Korba, B.E.; Schinazi, R.F.; Cote, P.; Tennant, B.C.; Gerin, J.L. Effect of oral administration of emtricitabine on woodchuck hepatitis virus replication in chronically infected woodchucks. Antimicrob. Agents Chemother. 2000, 44, 1757-1760.

147. Gish, R.G.; Trinh, H.; Leung, N.; Chan, F.K.; Fried, M.W.; Wright, T.L.; Wang, C.; Anderson, J.; Mondou, E.; Snow, A.; Sorbel, J.; Rousseau, F.; Corey, L. Safety and antiviral activity of emtricitabine (FTC) for the treatment of chronic hepatitis B infection: a two-year study. J. Hepatol. 2005, 43, 60-66.

148. Lim, S.G.; Krastev, Z.; Ng, T.M.; Mechkov, G.; Kotzev, I.A.; Chan, S.; Mondou, E.; Snow, A.; Sorbel, J.; Rousseau, F. Randomized, double-blind study of emtricitabine (FTC) plus clevudine versus FTC alone in treatment of chronic hepatitis B. Antimicrob. Agents Chemother. 2006, 50, 1642-1648.

149. Marcellin, P.; Mommeja-Marin, H.; Sacks, S.L.; Lau, G.K.; Sereni, D.; Bronowicki, J.P.; Conway, B.; Trepo, C.; Blum, M.R.; Yoo, B.C.; Mondou, E.; Sorbel, J.; Snow, A.; Rousseau, F.; Lee, H.S. A phase II dose-escalating trial of clevudine in patients with chronic hepatitis B. Hepatology 2004, 40, 140-148.

150. Goulis, I.; Dalekos, G.N. Entecavir monotherapy for lamivudine-refractory chronic hepatitis B. Expert Rev. Anti Infect. Ther. 2008, 6, 855-859.

151. Yoo, B.C.; Kim, J.H.; Chung, Y.H.; Lee, K.S.; Paik, S.W.; Ryu, S.H.; Han, B.H.; Han, J.Y.; Byun, K.S.; Cho, M.; Lee, H.J.; Kim, T.H.; Cho, S.H.; Park, J.W.; Um, SH.; Hwang, S.G.; Kim, Y.S.; Lee, Y.J.; Chon, C.Y.; Kim, B.I.; Lee, Y.S.; Yang, J.M.; Kim, H.C.; Hwang, J.S.; Choi, S.K.; Kweon, Y.O.; Jeong, S.H.; Lee, M.S.; Choi, J.Y.; Kim, D.G.; Kim, Y.S.; Lee, H.Y.; Yoo, K.; Yoo, H.W.; Lee, H.S. Twenty-four-week clevudine therapy showed potent and sustained antiviral activity in HBeAg-positive chronic hepatitis B. Hepatology 2007, 45, 1172 1178.

152. Yoo, B.C.; Kim, J.H.; Kim, T.H.; Koh, K.C.; Um, S.H.; Kim, Y.S.; Lee, K.S.; Han, B.H.; Chon, C.Y.; Han, J.Y.; Ryu, S.H.; Kim, H.C.; Byun, K.S.; Hwang, S.G.; Kim, B.I.; Cho, M.; Yoo, K.; Lee, H.J.; Hwang, J.S.; Kim, Y.S.; Lee, Y.S.; Choi, S.K.; Lee, Y.J.; Yang, J.M.; Park, J.W.; Lee, M.S.; Kim, D.G.; Chung, Y.H.; Cho, S.H.; Choi, J.Y.; Kweon, Y.O.; Lee, H.Y.; Jeong, S.H.; Yoo, H.W.; Lee, H.S. Clevudine is highly efficacious in hepatitis B e antigen-negative chronic hepatitis B with durable off-therapy viral suppression. Hepatology 2007, 46, 1041-1048.

153. Kim, B.K.; Oh, J.; Kwon, S.Y.; Choe, W.H.; Ko, S.Y.; Rhee, K.H.; Seo, T.H.; Lim, S.D.; Lee, C.H. Clevudine myopathy in patients with chronic hepatitis B. J. Hepatol. 2009; 51, 829-834. 
154. Seok, J.I.; Lee, D.K.; Lee, C.H.; Park, M.S.; Kim, S.Y.; Kim, H.S.; Jo, H.Y.; Lee, C.H.; Kim, D.S. Long-term therapy with clevudine for chronic hepatitis B can be associated with myopathy characterized by depletion of mitochondrial DNA. Hepatology 2009, 49, 2080-2086

155. European Association for the Study of the Liver. EASL Clinical practice guidelines: management of chronic hepatitis B. J. Hepatol. 2009, 50, 227-242.

156. Lok, A.S.F.; McMahon, B.J. AASLD Practice guidelines. Chronic hepatitis B: update 2009. Hepatology 2009, 50, 1-36.

157. Liaw, Y.-F.; Suh, D.J.; Omata, M. APASL guidelines for HBV management. Presented at the APASL Annual Meeting, Seoul, Korea, 2008

158. Piratvisuth, T. Reviews for APASL guidelines: immunomodulatory therapy of chronic hepatitis B. Hepatol. Int. 2008, 2, 140-146.

159.Zoulim F.; Perrillo, R. Hepatitis B reflections on the current approach to antiviral therapy. J. Hepatol. 2008, 48 (Suppl. 1), S2-S19.

160. Lampertico, P.; Vigano, M.; Manenti, E.; Iavarone, M.; Colombo, M. Add-on adefovir prevents the emergence of adefovir resistance in lamivudine-resistant patients: a 4-year study. J. Hepatol. 2008, 48, S259.

161. Fournier, C.; Zoulim, F. Antiviral therapy of chronic hepatitis B prevention of drug resistance. Clin. Liver Dis. 2007, 11, 869-892.

162. Papatheodoridis, G.V.; Manolakopoulos, S.; Dusheiko, G.; Archimandritis, A.J. Therapeutic strategies in the management of patients with chronic hepatitis B virus infection. Lancet Infect. Dis. 2008, 8, 167-178.

163. Lampertico, P.; Colombo, M. HBeAg-negative chronic hepatitis B: why do I treat my patients with nucleos(t)ide analogues. Liver Int. 2009, 29, 130-132.

164. Liaw, Y.F. On-treatment outcome prediction and adjustment during chronic hepatitis B therapy: now and future. Antiviral Ther. 2009, 14, 13-22.

(C) 2010 by the authors; licensee MDPI, Basel, Switzerland. This article is an Open Access article distributed under the terms and conditions of the Creative Commons Attribution license (http://creativecommons.org/licenses/by/3.0/). 